\title{
Intraovarian factors in ovulation: determinants of follicular response to gonadotrophins
}

\author{
H. R. Lindner, A. Amsterdam, Y. Salomon, A. Tsafriri, A. Nimrod, \\ S. A. Lamprecht, U. Zor and Y. Koch \\ Department of Hormone Research, The Weizmann Institute of Science, Rehovot, Israel
}

Summary. (1) Follicles vary greatly in their response to a hormonal stimulus. Some of the factors that influence the sensitivity of the rat follicle to ovulatory hormones are discussed in this review. (2) The responsiveness of the rat ovary to gonadotrophins undergoes striking augmentation during the 2 nd week of postnatal development with respect to cyclic AMP formation, cAMP-stimulated protein kinase activity, inducibility of ornithine decarboxylase and oestrogen secretion. (3) FSH, probably in concert with oestrogen, sensitizes the follicle to subsequent stimulation of adenylyl cyclase by LH. This synergism, based on heterologous receptor induction, operates during prepubertal as well as cyclic follicular maturation. (4) The ovarian LH-stimulated adenylyl cyclase possesses a guanine nucleotide regulatory site. Occupation of this site by GTP or $\mathrm{Gpp}(\mathrm{NH}) \mathrm{p}$ reduces the concentration of $\mathrm{LH}$ required for half-maximal stimulation of the enzyme and increases its activity $\left(\mathrm{V}_{\text {max }}\right)$. (5) Androgen synergizes FSH in stimulating progestin secretion by cultured immature granulosa cells, though the steroid is known to antagonize the FSH action on granulosa cell proliferation. Thecal androgen may be required for the maturation of the FSH response mechanism in granulosa cells of preantral follicles, while promoting atresia in large antral follicles. (6) Continued exposure of the follicle to high concentrations of LH, FSH, or PGE-2 results in refractoriness of adenylyl cyclase to further stimulation by the same hormone. Desensitization may be transient (PGE-2) or protracted (LH) and seems to depend on the synthesis of a macromolecular inhibitor that affects the coupling between hormone receptor and adenylyl cyclase. This mechanism may account for the shut-down of follicular steroid production at ovulation, which depends on cAMP, and permit the expression of processes that are inhibited by cAMP. (7) Granulosa cells exert a restraining influence on oocyte maturation which may be transmitted by direct contact and perhaps by substances released into the follicular fluid; this inhibition is reversed by LH. The sensitivity of the oocyte to the meiosis-triggering action of LH increases, and its susceptibility to inhibition by follicular fluid extracts decreases, during the final stages of preovulatory development. (8) Specific binding sites for $\mathbf{L H}$ are restricted to the theca interna and the peripheral layers of the membrana granulosa of the preovulatory follicle. Extensive gap junctions between granulosa cells provide an anatomical basis for the propagation of the signal generated by $\mathrm{LH}$ to the interior of the follicle. The presence of such gap junctions between cytoplasmic extensions of the coronal cells and the oocyte may serve to control the membrane potential of the oocyte by electrical coupling. Depolarization of this membrane precedes ovum maturation in non-mammalian species. (9) Prostaglandin synthesis within the follicle is stimulated by $\mathrm{LH}$ and is essential for LH-induced follicular rupture. Cells of the external theca contain abundant microfilaments and are rich in actin and smooth-muscle myosin, demonstrable by immunofluorescence. These smooth muscle-like cells may be a target for prostaglandins and/or adrenergic neurotransmitters during ovulation and assist extrusion of the cumulus mass. (10) Actin and myosin occur beneath the oolemma of the mammalian oocyte and may play a part in the dynamics of the maturation divisions. (11) Thecal and granulosa cells in ovarian slices incorporate ${ }^{35} \mathrm{SO}_{4}$ into chondroitin sulphates and 
heparin-like substances and rapidly secrete these into the antral fluid. LH suppresses the synthesis of these sulphated glycosaminoglycans; progesterone probably mediates this inhibition. Since the antral S-GAGs include heparin, this secretion may have regulatory actions within the follicle beyond the hydrodynamic effects postulated earlier. (12) Delayed effects of hormones on the sensitivity of the follicle to the same hormone or to the action of a heterologous hormone, and the successive appearance and redistribution of different hormone receptors and specialized membrane components may be significant elements in the programming of a precisely timed developmental sequence that is a characteristic feature of the life history of the follicle.

Earlier speakers at this Symposium have discussed how the periodic discharges of gonadotrophins, on which ovulation depends, might be controlled. The purpose of this paper is to consider some of the factors operating within the ovary that alter the responsiveness of individual follicles to the ovulatory action of these gonadotrophin surges.

The ovulatory response is a composite one, consisting of at least three distinct components: the re-initiation of the meiotic process in the oocyte; a shift from follicular oestrogen to progesterone production with early luteinization of the granulosa cell; and breakdown of the follicle wall with delivery of a fertilizable oocyte. All three processes are probably initiated by a similar interaction of gonadotrophins with membrane-bound receptors in the appropriate follicular compartment, but subsequent expression of the response will depend, in each case, on disparate mechanisms. We propose to discuss how the sensitivity of the rat follicle with respect to these three responses can be experimentally modified, and how it changes during crucial phases of development. In addition, we will draw attention to a number of structural features, which have recently come to light, that exhibit striking changes in the course of follicular development and, we feel, may be relevant to the ovulatory process. These include the appearance of contractile proteins in the follicle wall and the presence of specialized membrane junctions between the cells of the preovulatory follicle.

While undoubtedly many factors affect the follicular response to gonadotrophin, this review will be restricted to those currently under investigation in our laboratory and to findings more recent than those reviewed by Lindner et al. (1974a, b).

\section{Acquisition of responsiveness to gonadotrophins during postnatal development}

The minimal requirements for a cellular response to gonadotrophins are now held to include (i) the presence of specific recognition sites for FSH and LH on the cell membrane (Lunenfeld \& Eshkol, 1967; Kammerman, Canfield, Kolena \& Channing, 1972; Lee \& Ryan, 1972: Koch et al., 1974; Richards \& Midgley, 1976); (ii) the membrane-bound enzyme adenylyl cyclase; (iii) effective coupling between these two components (Marsh, Butcher, Savard \& Sutherland, 1966; Kolena \& Channing,

Table 1. Mean \pm S.E.M. production of $3^{\prime}: 5^{\prime}$ cyclic AMP (from $\left[{ }^{3} \mathrm{H}\right.$ ]adenine-labelled ATP) by rat ovaries in vitro ( $15 \mathrm{~min}$ incubation) in response to $10 \mu \mathrm{g} \mathrm{H} / \mathrm{ml}$ as a function of age

\begin{tabular}{cc}
\hline $\begin{array}{c}\text { Age } \\
\text { (days from birth) }\end{array}$ & $\begin{array}{c}\text { cAMP production } \\
\text { (\% over control) }\end{array}$ \\
\hline-1 & $69 \pm 28$ \\
+2 & $8 \cdot 1 \pm 9 \cdot 0$ \\
5 & $13 \pm 8 \cdot 5$ \\
8 & $122 \pm 12$ \\
11 & $278 \pm 39$ \\
14 & $620 \pm 22$ \\
18 & $692 \pm 145$ \\
30 & $719 \pm 57$ \\
\hline
\end{tabular}

Condensed from Lamprecht et al. (1973). 
Table 2. The protein kinase response of rat ovarian homogenates to exogenous cyclic AMP $\left(5 \times 10^{-5} \mathrm{M}\right)$ as a function of age

\begin{tabular}{cc}
\hline $\begin{array}{c}\text { Age } \\
\text { (days) }\end{array}$ & ${ }^{32}$ P incorporation (\% over control) \\
\hline 7 & $35 \pm 21$ \\
8 & 104 \\
9 & 214 \\
10 & 278 \\
12 & $381 \pm 49$ \\
28 & $516 \pm 54$ \\
\hline
\end{tabular}

The results are means of duplicates or mean \pm S.E.M. $(n=4)$. The substrate was calf thymus histone. Data from Lamprecht et al. (1973) and unpublished observations.

1972; Tsafriri, Lindner, Zor \& Lamprecht, 1972; Lamprecht, Zor, Tsafriri \& Lindner, 1973; Ahrén et al., 1974; Hunzicker-Dunn, 1977); and (iv) cyclic AMP stimulated protein kinase(s), probably capable of modifying the activity of as yet unidentified regulatory proteins in the cytoplasm or chromatin (Kuo \& Greengard, 1969; Lamprecht et al., 1973). In the ovaries of 1-6-day-old rats these conditions are not yet realized: at this stage of development, the ovary fails to respond to LH with increased cyclic AMP production or the response is minimal (Table 1) and though it contains demonstrable basal protein kinase activity, the enzyme is not stimulated by exogenous cyclic AMP (Table 2). Both responses appear during the 2 nd week of postnatal development and at the same time the ovary acquires the capacity to respond to $\mathrm{LH}$ with increased oestradiol-17ß release (Text-fig. 1) and ornithine decarboxylase activity (Kaye et al., 1973a). The latter enzyme, which is rate-limiting in polyamine synthesis, is induced by many hormones that stimulate growth and cell division in other

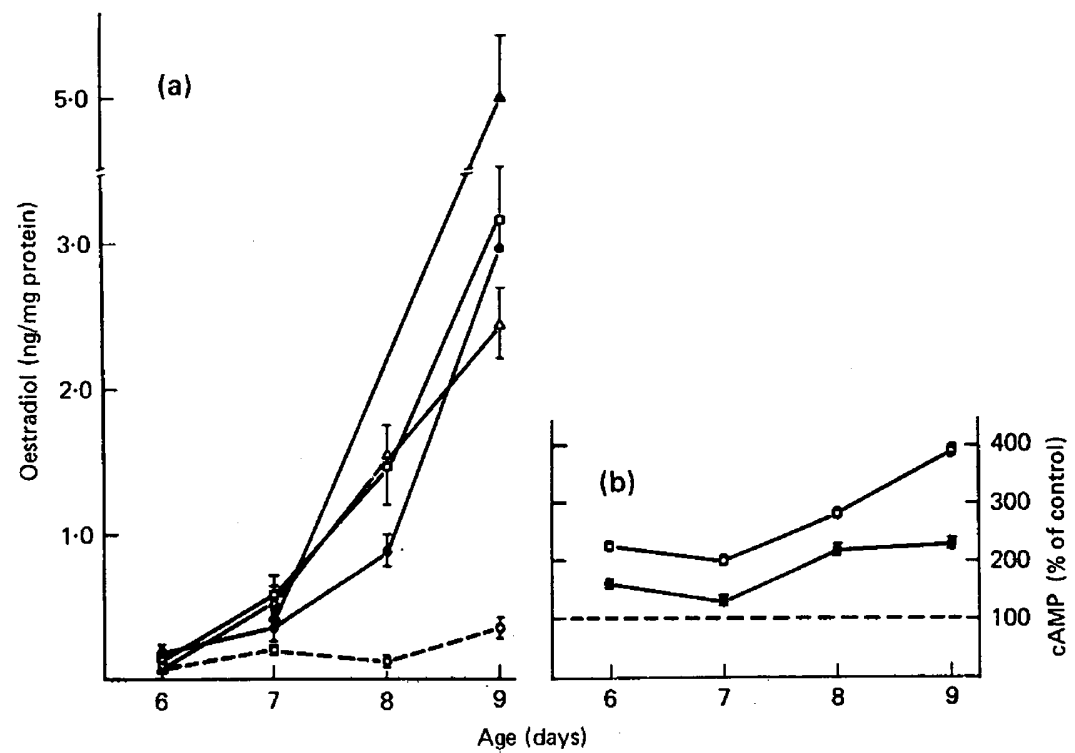

Text-fig. 1. Effect of age on (a) oestradiol release and (b) cyclic AMP accumulation in vitro by rat ovaries in response to hormones. Oestradiol accumulation (mean \pm S.E.M.) in the medium during a 4-h incubation with (๑) $10 \mu \mathrm{g} \mathrm{LH} / \mathrm{ml},(\triangle) 70 \mu \mathrm{g} \mathrm{FSH} / \mathrm{ml}$, ( $\square) 10 \mu \mathrm{g} \mathrm{PGE}-2 / \mathrm{ml},(\Delta) 1.0 \mathrm{~mm}-8$-bromo-adenosine $3^{\prime}: 5^{\prime}$-cyclic monophosphoric acid or $(O)$ in control medium in relation to weight of ovarian protein. From Lamprecht et al. (1976a). 
tissues (e.g. prostate: Pegg, Lockwood \& Williams-Ashman, 1970; uterus: Kaye, Icekson \& Lindner, 1971) and is highly responsive to $\mathrm{LH}$ in the Graafian follicle of the mature rat (Icekson et al., 1974). A significant steroidogenic response to FSH and PGE-2 was first demonstrable by the 7th day of postnatal development and seemed to precede the ability to respond to LH by $24 \mathrm{~h}$ (Text-fig. 1) (Lamprecht, Kohen, Ausher, Zor \& Lindner, 1976a).

There is evidence that gonadotrophins are secreted in the rat during the 2nd week of life (Goldman, Grazia, Kamberi \& Porter, 1971; Meijs-Roelofs, Uilenbroek, de Jong \& Welschen, 1973), and that the uterus gradually acquires responsiveness to oestrogen during the first 3 weeks of postnatal life (Kaye et al., 1973b). In the present context, however, the major significance of the early follicular oestrogen secretion probably lies in its effect on subsequent follicular growth and the generation of LH-receptors in the granulosa cells (see below).

\section{FSH/LH synergism in the maturing follicle}

Ovarian homogenates from prepubertal rats (27 days old) contain demonstrable adenylyl cyclase activity which can be stimulated to a moderate degree by LH (Salomon, Yanovsky, \& Lindner, 1976). Treatment of the rats with PMSG (15 i.u./rat) on Day 25 greatly enhanced the response of the ovarian adenylyl cyclase to ovine $\mathrm{LH}$ measured $48 \mathrm{~h}$ later under a variety of assay conditions (Table 3) and brought it to a level similar to that observed in preovulatory Graafian follicles from mature rats (Text-fig. 2). A smaller PMSG effect was observed at $36 \mathrm{~h}$ and there was no effect at $24 \mathrm{~h}$ after injection.

Table 3. Effect of PMSG on LH-sensitive adenylyl cyclase in ovarian homogenates of immature rats

\begin{tabular}{lcc}
\hline & \multicolumn{2}{c}{$\begin{array}{c}\text { Adenylate cyclase activity } \\
\text { (pmol cAMP/15 min/mg protein) }\end{array}$} \\
\cline { 2 - 3 } $\begin{array}{l}\text { Substances added } \\
\text { during assay }\end{array}$ & $\begin{array}{c}\text { Untreated } \\
\text { rats }\end{array}$ & $\begin{array}{c}\text { PMSG-treated } \\
\text { rats }\end{array}$ \\
\hline None & $81 \pm 5$ & $97 \pm 4$ \\
GTP $\left(10^{-5}\right.$ M) & $169 \pm 6$ & $210 \pm 3$ \\
Ovine LH $(3 \mu \mathrm{g} / \mathrm{ml})$ & $159 \pm 12$ & $437 \pm 9$ \\
Ovine LH + GTP & $398 \pm 9$ & $741 \pm 72$ \\
\hline
\end{tabular}

PMSG (15 i.u./rat) was given on the morning of Day 25 and ovaries were collected $48 \mathrm{~h}$ later. Values are mean \pm S.E.M. $(n=4)$ for two independent experiments, each performed in duplicate. Y. Salomon, A. Yanovsky \& H. R. Lindner, unpublished observations.

Table 4. Induction of LH-binding sites on granulosa cells in organ cultures of ovarian fragments from oestrogen-primed, hypophysectomized immature rats

\begin{tabular}{ll}
\hline Culture conditions & $\begin{array}{c}\text { HCG binding } \\
\text { (fmol/106 cells) }\end{array}$ \\
\hline No additions & $0.26 \pm 0.03(22)$ \\
FSH (LER-1801-3;0.1 $\mu \mathrm{g} / \mathrm{ml})$ & $1 \cdot 19 \pm 0.17(20)$ \\
8-bromo-cAMP $(1.0 \mathrm{mM})$ & $0.25 \pm 0.08(4)$ \\
\hline
\end{tabular}

Granulosa cells were harvested after $48 \mathrm{~h}$ of incubation, pooling cells from two ovaries, and ${ }^{125}$ I-labelled HCG binding was determined in triplicate for each pool. Values are mean \pm S.E.M. for the number of cell pools shown in parentheses. A Nimrod, A. Tsafriri \& H. R. Lindner, unpublished data. 


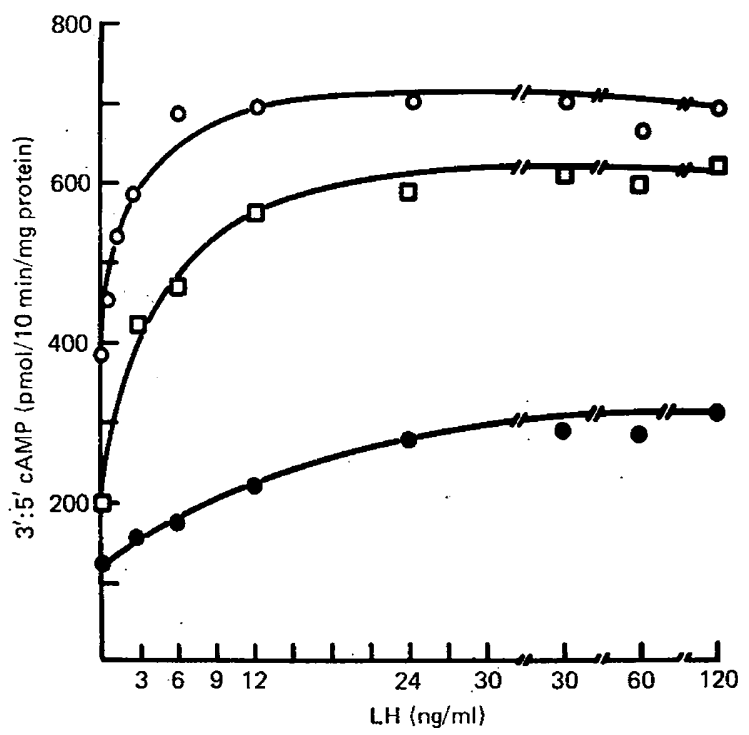

Text-fig. 2. Effect of guanine nucleotides on adenylyl cyclase response to ovine LH in homogenates of rat ovarian follicles. Follicles were isolated on the day of pro-oestrus between 10.00 and $12.00 \mathrm{~h}$ and homogenized in $10 \mathrm{~mm}$-tris-acetate buffer, $\mathrm{pH} 7 \cdot 6$, containing $1.0 \mathrm{~mm}$-DTT (10 follicles $/ \mathrm{ml})$. For each assay the equivalent of $1 / 5$ of a follicle (about $4-5 \mu \mathrm{g}$ protein) was used. Assay conditions as described in legend to Table 7, except that $\mathrm{Mg}^{++}$concentration was $5.0 \mathrm{~mm}$ and ATP was $0.5 \mathrm{mM}$. $\bullet$, Control; $\square, 10 \mu \mathrm{M}$-guanidine triphosphate; O, $10 \mu \mathrm{M}$-guanylyl-imido-diphosphate. Data from Salomon et al. (1976) and unpublished observations.

PMSG has predominantly FSH-like activity; it stimulates oestrogen secretion in the prepubertal ovary and induces massive synchronized follicular growth. The elegant studies by Richards \& Midgley (1976) established that oestrogen synergizes with FSH in inducing specific LH-binding sites in the developing follicle in vivo. The results shown in Table 3 are compatible with this hypothesis and provide evidence that $\mathrm{LH}$-binding sites induced in this way are effectively coupled to an adenylate cyclase, justifying their designation as LH receptors. Furthermore, we have now been able to demonstrate the induction by FSH in vitro of LH-binding sites in granulosa cells from oestrogen-primed preantral follicles (Nimrod, Tsafriri \& Lindner, 1977): 20-day-old rats were hypophysectomized and treated with diethylstilboestrol $(0.5 \mathrm{mg} / \mathrm{rat} / \mathrm{day})$ for 4 days. A 5 -fold increase in the number of LHbinding sites/granulosa cell resulted when ovarian fragments from such animals were maintained in organ culture with FSH for $48 \mathrm{~h}$ (Table 4), and increased cAMP formation in response to LH was observed after $96 \mathrm{~h}$ of culture with FSH (A. Nimrod, unpublished observations). The effect of FSH on LH binding was not mimicked by 8-bromo-cAMP $(1.0 \mathrm{~mm})$, suggesting that this action of FSH may be independent of the cyclic nucleotide. In contrast to the behaviour of organ cultures containing intact follicles, no induction of LH-binding sites by FSH was achieved when isolated immature granulosa cells from oestrogen-treated rats were grown as monolayers. This suggests that the effect may depend on an interaction with other cellular components of the follicle.

We can thus envisage a developmental sequence of events in which FSH prepares the membrana granulosa for oestrogen production (see Dorrington, Moon \& Armstrong, 1975), and the two hormones jointly sensitize the follicle to the subsequent action of LH. A similar sequence may take place during cyclic maturation of follicles in the adult rat: LH-binding to granulosa cells of enlarged follicles (E. Bedrak, A. Nimrod, \& H. R. Lindner, unpublished observations), as well as the responsiveness of follicular adenylyl cyclase to LH (Hunzicker-Dunn \& Birnbaumer, 1975), were found to be low at oestrus and metoestrus, but began to increase on the evening of dioestrus (when oestrogen levels are rising; Lindner et al., 1974a) to reach a peak at pro-oestrus before the preovulatory surge of LH. 
Interaction of ovarian adenylyl cyclase with guanine nucleotides

Adenylyl cyclases from many eukaryote cells, including adipocytes and hepatocytes (Salomon \& Rodbell, 1975), have specific binding sites for guanine nucleotides. Occupation of these sites by GTP, or by its imido analogue, $\mathrm{Gpp}(\mathrm{NH}) \mathrm{p}$, which is more resistant to nucleotide-phosphohydrolase, increases the basal activity of the enzyme and its response to the respective hormone (Rodbell, Lin \& Salomon, 1974). Adenylyl cyclase in homogenates from isolated preovulatory rat follicles also possess a guanine nucleotide regulatory site (Salomon, Yanovsky \& Lindner, 1976); addition of either guanosine nucleotide at $10^{-5} \mathrm{M}$ concentration increased the sensitivity of the enzyme to $\mathrm{LH}$, so that half-maximal stimulation occurred at 10 -fold lower concentration $(3 \mathrm{ng} / \mathrm{ml} ; \mathrm{NIH}-\mathrm{LH}-\mathrm{S} 18)$ and maximal activity was increased 2-3-fold in the presence of optimal Mg concentrations (Text-fig. 2). Whether the concentration of guanine nucleotides in the relevant cellular compartment ever limits the response of the follicle to $\mathrm{LH}$ in vivo has not been established.

\section{Androgen/FSH synergism and antagonism}

The interactions between androgens and FSH within the follicle are complex, but their definition may be crucial for an understanding of follicular development. The granulosa cell is endowed with a cytoplasmic androgen receptor (Schreiber, Reid \& Ross, 1976) the physiological role of which has been an enigma. Androstenedione and testosterone are formed mainly, if not exclusively, in the thecal compartment (Makris \& Ryan, 1975), but androgen may also reach the follicle from adjacent interstitial cells (Louvet, Harman, Schreiber \& Ross, 1975). It has been observed that exogenous androgen promoted follicular atresia (Payne \& Runsen, 1958) and Louvet, Harman \& Ross (1975) proposed that ovarian androgen, secreted in response to $\mathrm{LH}$, restrained the mitogenic action of oestrogen on the granulosa cells of preantral follicles. These findings suggest that the ultimate fate of a follicle may well depend on the balance between androgen accumulation and oestrogen formation at a critical stage of development: an early induction of aromatase in the granulosa cell by FSH (Dorrington $e t$ al., 1975) would reduce the probability of androgen-induced atresia while favouring oestrogeninduced follicular growth and generation of the LH receptor (see above).

In view of this negative role currently assigned to androgen in follicular development we were surprised to find a synergistic relationship between androgen and FSH when studying a different response, namely steroidogenesis in cultured granulosa cells (Nimrod \& Lindner, 1976). The granulosa cells were derived either from preovulatory follicles of mature rats or from the enlarged preantral follicles generated in immature hypophysectomized rats by treatment with diethylstilboestrol $(0.5 \mathrm{mg} / \mathrm{rat} /$ day) for 5 days (Hx-DES cells). In Hx-DES cells, basal production of progesterone and $20 \alpha$-dihydroprogesterone during a $48 \mathrm{~h}$ incubation period was low by comparison with that of preovulatory follicle cells (about one-fifth) and increased only 2-fold in response to FSH or androstenedione when either hormone was added alone. However, combined treatment of Hx-DES cells with androgen (androstenedione, testosterone or $5 \alpha$-dihydrotestosterone) and FSH caused a 10-fold greater increase in progestin formation over the values attained with FSH alone (Table 5). The minimal concentration of FSH able to elicit a steroidogenic response in these cultures was reduced from $>4 \mathrm{ng} / \mathrm{ml}$, in the absence of androstenedione, to $0.8 \mathrm{ng} / \mathrm{ml}$ in the presence of the steroid (A. Nimrod, unpublished observations). Androgen also exerted a significant, though smaller, synergistic action on progestagen production in preovulatory granulosa cells. Oestradiol failed to synergize the steroidogenic action of FSH in either cell type, so that the effects of androgens cannot be attributed to their aromatization (Table 5). When the culture period was extended to 4 days, responsiveness to FSH was entirely lost unless androgen was present from the start of the culture period. Maximal production of $20 \alpha$-dihydroprogesterone, up to 100 times the basal level, was attained when both FSH and androgen were present throughout the culture period (Table 6).

FSH has been shown to have an intrinsic stimulatory action on follicular adenylyl cyclase and steroidogenesis (Koch, Zor, Pomerantz, Chobsieng \& Lindner, 1973; Tsafriri et al., 1976a). Furthermore, LH is not steroidogenic to cultured Hx-DES cells, so that the steroidogenic effect of FSH in this model cannot be due to LH contamination of the FSH preparation. On the other hand, these 
Table 5. Accumulation of progesterone in the medium during the first $48 \mathrm{~h}$ of culture of granulosa cells (from enlarged preantral follicles of immature hypophystectomized rats treated with $0.5 \mathrm{mg}$ diethylstilboestrol/rat/day for 5 days) showing the synergism between FSH and androstenedione (Ad)

\begin{tabular}{|c|c|c|}
\hline \multirow{2}{*}{$\begin{array}{c}\text { Substances } \\
\text { added } \\
\text { (other than Ad) }\end{array}$} & \multicolumn{2}{|c|}{$\begin{array}{l}\text { Progesterone accumulation } \\
\qquad\left(10^{-15} \mathrm{~g} / \text { cell } / 48 \mathrm{~h}\right)\end{array}$} \\
\hline & Without Ad & With Ad $(1 \mu \mathrm{g} / \mathrm{ml})$ \\
\hline None (control) & $7 \cdot 2 \pm 0.2$ & $19 \cdot 0 \pm 1 \cdot 6$ \\
\hline Human FSH $(0.1 \mu \mathrm{g} / \mathrm{ml})$ & $17 \cdot 0 \pm 2 \cdot 3$ & $241 \pm 13$ \\
\hline Dibutyryl cyclic AMP (1.0 mM) & $128 \pm 5$ & $267 \pm 8$ \\
\hline Oestradiol-17ß $(1 \mu \mathrm{g} / \mathrm{ml})$ & $8 \cdot 5 \pm 0.4$ & $18.6 \pm 0.5$ \\
\hline Oestradiol + FSH & $22 \cdot 2 \pm 0.7$ & - \\
\hline Oestradiol + dbcAMP & $141 \pm 7$ & - \\
\hline
\end{tabular}

Values are mean \pm S.E.M., $n=4$.

Data from Nimrod et al. (1976).

Table 6. Synergistic effect of FSH and androstenedione on sustained production of $20 \alpha$ dihydroprogesterone in cultured granulosa cells from preantral follicles of rats (see Table 5)

\begin{tabular}{|c|c|c|c|}
\hline \multicolumn{2}{|c|}{ Culture conditions } & \multicolumn{2}{|c|}{$\begin{array}{c}20 \mathrm{a}-\mathrm{OH}-\mathrm{P} \text { accumulation } \\
\text { (ng/dish } / 48 \mathrm{~h} \text { ) }\end{array}$} \\
\hline Days 1-2 & Days $3-4$ & Days 1-2 & Days $3-4$ \\
\hline No hormones & $\begin{array}{l}\text { No hormones } \\
\text { FSH } \\
\text { Androstenedione } \\
\text { FSH + androstenedione }\end{array}$ & $84 \cdot 6 \pm 24 \cdot 0$ & $\begin{array}{l}14.9 \pm 0.4 \\
26 \cdot 0 \pm 4 \cdot 1 \\
18 \cdot 8 \pm 2 \cdot 1 \\
56.7 \pm 3.8\end{array}$ \\
\hline FSH & $\begin{array}{l}\text { No hormones } \\
\text { FSH } \\
\text { Androstenedione } \\
\text { FSH + androstenedione }\end{array}$ & $212 \pm 3$ & $\begin{array}{c}48.4 \pm 6.4 \\
67.4 \pm 2.4 \\
81.8 \pm 4.4 \\
144 \pm 23\end{array}$ \\
\hline Androstenedione & $\begin{array}{l}\text { No hormones } \\
\text { FSH } \\
\text { Androstenedione } \\
\text { FSH + androstenedione }\end{array}$ & $245 \pm 25$ & $\begin{array}{l}113 \pm 4 \\
371 \pm 62 \\
212 \pm 21 \\
558 \pm 114\end{array}$ \\
\hline FSH + androstenedione & $\begin{array}{l}\text { No hormones } \\
\text { FSH } \\
\text { Androstenedione } \\
\text { FSH + androstenedione }\end{array}$ & $774 \pm 36$ & $\begin{array}{c}812 \pm 34 \\
1281 \pm 286 \\
945 \pm 204 \\
2070 \pm 75\end{array}$ \\
\hline
\end{tabular}

Data from A. Nimrod (unpublished).

cells are rich in specific FSH-binding sites (Zeleznik, Midgley \& Reichert, 1974; Nimrod, Erickson \& Ryan, 1976) and endowed with steroidogenic enzymes, as shown by a high level of progestagen formation in response to dibutyryl cyclic AMP (Table 5). Is androgen required for the effective coupling between pre-existing FSH binding sites and a potential FSH-stimulated adenylyl cyclase? And does androgen-induced differentiation of the granulosa cells terminate an oestrogen-induced proliferative phase? These questions remain to be answered. The present findings, suggesting that theca-derived androgen serves to enhance the sensitivity of the FSH-responsive mechanism in early granulosa cells, may throw new light on the observation that an advanced stage of thecal development is essential for initiating ovarian responsiveness to gonadotrophins (Eshkol \& Lunenfeld, 1972; Goldenberg, Reiter \& Ross, 1973). In trying to reconcile well documented but opposite types of androgen/FSH interactions it may be worth bearing in mind that atresia, in which the 
FSH-antagonizing activity of androgen has been implicated, is now believed to affect only large follicles that have entered their final stages of development, whereas androgen/FSH synergism is most strikingly evident at preantral stages.

\section{Desensitization of follicular adenylyl cyclase to hormonal stimulation}

An extreme example of altered follicular sensitivity to hormonal stimulation is the refractory state which develops when preovulatory rat follicles are cultured in the presence of high concentrations of LH, FSH or PGE-2 (Text-fig. 3). When rinsed and challenged with fresh hormone after increasing time intervals, such follicles were found to have progressively lost their sensitivity to the corresponding hormone: after $24 \mathrm{~h}$ culture, cyclic AMP accumulation in response to LH, FSH and PGE-2, determined in the presence of inhibitors of phosphodiesterase, was reduced by 80,50 and $90 \%$ respectively (Lamprecht et al., 1973; Zor, Lamprecht, Koch \& Lindner, 1975; Zor, Lamprecht, Misulovin, Koch \& Lindner, 1976). Refractoriness was specifically restricted to the homologous hormone, so that follicles desensitized to $\mathrm{LH}$ remained fully responsive to FSH (Zor et al., 1976) and PGE-2 (Text-fig. 4). Desensitization was maximal within 4-6 h during culture with PGE-2 (0.25-10 $\mu \mathrm{g} / \mathrm{ml}$ ), but required $9-12 \mathrm{~h}$ with $\mathrm{LH}$ (Text-fig. 3 ). The process was readily reversible in the case of PGE-2, but follicles refractory to LH did not regain their responsiveness during an 8-h incubation in hormone-free medium, even after stripping bound hormone with anti-LH serum (Lamprecht, Zor, Koch, Salomon, \& Lindner, 1977). The concentration of LH required to induce desensitization $(0.8 \mu \mathrm{g} / \mathrm{ml}$; Zor et al., 1975) was larger than the minimal effective dose for stimulation of cyclic AMP production $(0 \cdot 1-0.4 \mu \mathrm{g} / \mathrm{ml})$. In homogenates from isolated follicles exposed for $24 \mathrm{~h}$ to $\mathrm{LH}$, adenylyl

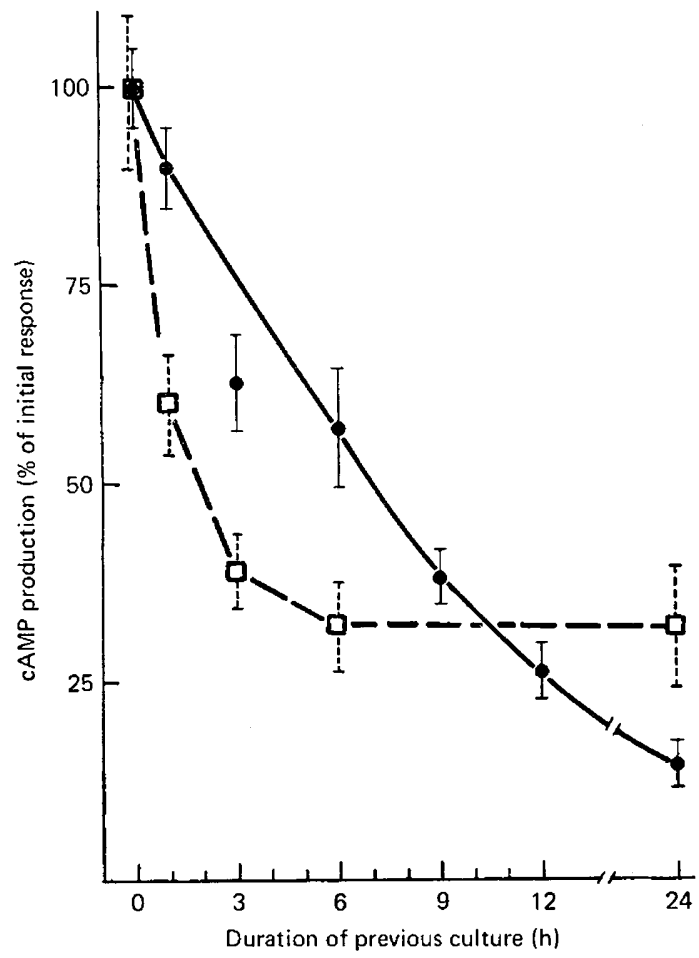

Text-fig. 3. Time course of desensitization of rat Graafian follicles to LH (e) or PGE-2 ( $\square$ ). The LH and PG $(10 \mu \mathrm{g} / \mathrm{ml})$ were present in the medium during all or none of the 24-h culture period or during the last 3-12 $\mathrm{h}$ as shown. After rinsing, the follicles were incubated for $30 \mathrm{~min}$ in fresh medium containing the same hormone and 3-isobutyl-1-methylxanthine (IBMX; $100 \mathrm{mg} / \mathrm{ml}$ ); cyclic AMP was then determined by a modification of the Gilman competitive protein-binding assay. Vertical bars, S.E.M. Condensed from Lamprecht et al. (1977). 


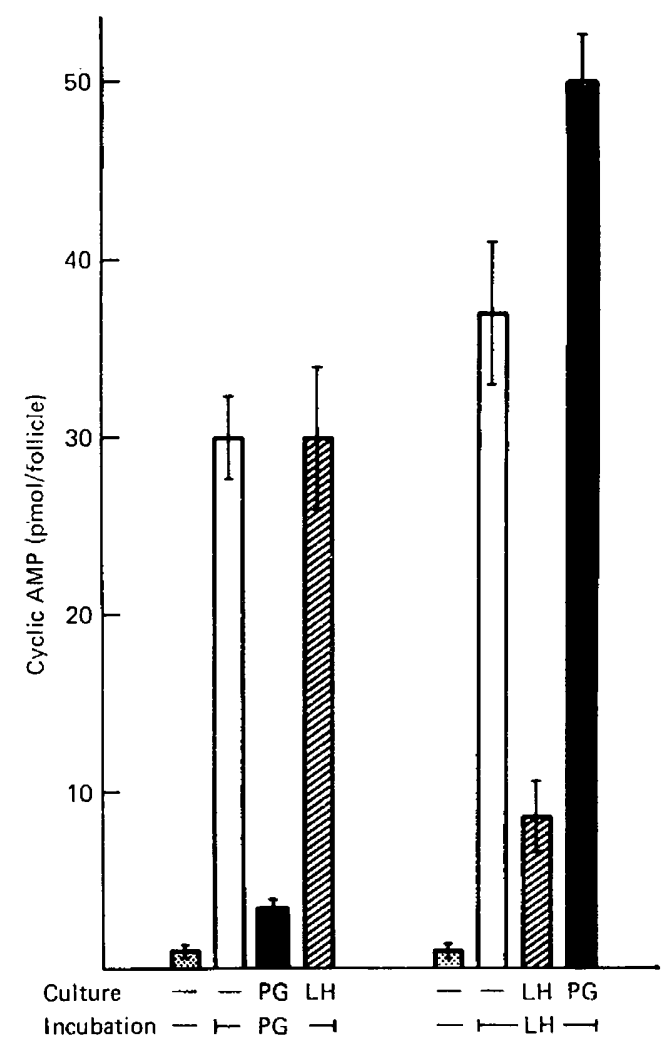

Text-fig. 4. Specificity of the effect of continued exposure of Graafian follicles to LH or PGE-2 on subsequent cAMP production in response to hormonal stimulation. After 24 h culture in hormone-free medium or with the LH or PGE-2 $(10 \mu \mathrm{g} / \mathrm{ml})$, the follicles were challenged for 30 min with fresh hormone (homologous or heterologous) and IBMX as described in the legend to Text-fig. 3. Mean values \pm S.E.M. $(n=18)$ are shown. Condensed from Zor et al. (1976).

cyclase failed to respond to LH, but responded fully to NaF, GTP or Gpp(NH)p with increased cyclic AMP formation (Table 7; Lamprecht et al., 1976b, 1977).

Graafian follicles from oestrous rabbits have been shown to lose their capacity to accumulate cyclic AMP before the time of HCG-induced ovulation (Marsh, Mills \& LeMaire, 1973), and HCG fails to promote a steroidogenic response in rabbit follicles approaching ovulation (Mills, Telegdy \& Savard, 1972). A similar desensitization of the cyclic AMP generating system to LH in vivo is observed at ovulation in the rat (Hunzicker-Dunn \& Birnbaumer, 1975; Nilsson, Hillensjö \& Ekholm, 1977). Hunzicker-Dunn (1977) confirmed that the gonadotrophin-induced decline in cyclic AMP accumulation in rat and rabbit follicles was indeed due to desensitization of adenylyl cyclase itself, and showed that in the rabbit this process was extremely rapid, with a $50 \%$ decline in responsiveness within $5 \mathrm{~min}$, and that it persisted for $48 \mathrm{~h}$ after HCG injection. In the rat, desensitization of follicular adenylyl cyclase occurred at the time of spontaneous ovulation and was prevented when the endogenous LH surge was blocked by Nembutal (Hunzicker-Dunn, 1977; Nilsson et al., 1977).

To account for the LH-induced desensitization of the follicle, a number of possible mechanisms have been considered. The continued responsiveness of refractory follicles to NaF, GTP and Gpp(NH)p implies that the perturbation is not at the level of the catalytic site or the nucleotide regulatory site. Likewise, there is evidence that refractoriness is not caused by an increased rate of cyclic AMP degradation due to increased phosphodiesterase activity or to a restriction in available ATP, since this substrate was not limiting in the conditions of the adenylyl cyclase assay (Lamprecht et al., 1977). Rao (1977) reported a reduction in available binding sites for LH in the ovary 
Table 7. Desensitization of LH-sensitive adenylate cyclase (as \% of basal activity) in homogenates of rat Graafian follicles

\begin{tabular}{|c|c|c|c|}
\hline \multirow{2}{*}{$\begin{array}{l}\text { Assay conditions } \\
\quad(15 \mathrm{~min})\end{array}$} & \multicolumn{3}{|c|}{ Preincubation with ovine LH ( $24 \mathrm{~h})$} \\
\hline & None & $1 \mu \mathrm{g} / \mathrm{ml}$ & $10 \mu \mathrm{g} / \mathrm{ml}$ \\
\hline Basal & 100 & 100 & 100 \\
\hline LH $(3 \mu \mathrm{g} / \mathrm{ml})$ & 383 & 118 & 100 \\
\hline GTP $(10 \mu \mathrm{M})$ & 141 & 157 & 140 \\
\hline $\operatorname{GTP}(10 \mu \mathrm{M})+\mathrm{LH}(3 \mu \mathrm{g} / \mathrm{ml})$ & 516 & 152 & 130 \\
\hline $\mathrm{Gpp}(\mathrm{NH}) \mathrm{p}(10 \mu \mathrm{M})$ & 308 & 257 & 175 \\
\hline $\mathrm{Gpp}(\mathrm{NH}) \mathrm{p}(10 \mu \mathrm{M})+\mathrm{LH}(3 \mu \mathrm{g} / \mathrm{ml})$ & 616 & 237 & 205 \\
\hline $\mathrm{NaF}(10 \mathrm{~mm})$ & 291 & 228 & 220 \\
\hline $\begin{array}{l}\text { Basal activity: } \\
\text { cyclic AMP formed }(\mathrm{pmol}) / 15 \mathrm{~min} / \mathrm{mg} \text { protein }\end{array}$ & 100 & 175 & 166 \\
\hline
\end{tabular}

Preovulatory follicles (6/treatment group) collected on the morning of pro-oestrus were incubated for $24 \mathrm{~h}$ with the hormone specified. Follicles were then rinsed and homogenized, and adenylate cyclase was assayed essentially as described by Salomon, Londos \& Rodbell (1974) in a medium containing $25 \mathrm{~mm}$-tris-acetate buffer, $\mathrm{pH} 7.6,2 \mathrm{~mm}$-magnesium acetate, $1.0 \mathrm{~mm}-\left[\alpha-{ }^{32} \mathrm{P}\right] \mathrm{ATP}\left(2-3 \times 10^{6} \mathrm{ct} / \mathrm{min} / \mathrm{flask}\right), 0.05 \mathrm{~mm}$-cyclic AMP, $1 \mathrm{~mm}-\mathrm{DTT}, 5 \mathrm{~mm}-$ creatine phosphate, 50 units creatine phosphokinase $/ \mathrm{ml}$ and $0.1 \mathrm{mg} \mathrm{BSA} / \mathrm{ml}$. From unpublished data of Y. Salomon, A. Yanovsky \& H. R. Lindner.

following administration of the hormone to rats. However, this would appear to be a later effect, since no appreciable change in available binding sites was observed 6-12 h after hormone administration, and we could not demonstrate a significant loss of binding sites for LH at a time when 'tachyphylaxis' to the hormone was fully established (Lamprecht et al., 1977). Moreover, desensitization to LH and FSH is homospecific, whereas the loss of binding sites reported by Rao (1977) following treatment with either hormone was not.

If, then, neither hormone binding nor the catalytic site of adenylyl cyclase is directly affected, it is possible that defective coupling of the hormone-receptor complex to the catalytic site is responsible for the refractory state. Interestingly, addition of actinomycin $D(8 \mu \mathrm{M})$ or cycloheximide $(30 \mu \mathrm{M})$ to the medium, together with the hormone, prevented the development of refractoriness to PGE-2 during a 6-h incubation (Lamprecht et al., 1977). Actinomycin D also reduced desensitization of follicles to LH during $9 \mathrm{~h}$ of incubation (Table 8) and puromycin or cycloheximide prolonged the effect of LH on cyclic AMP accumulation by rat ovaries in vitro (Bergh \& Ahrén, 1976). These results point to the possibility that desensitization may depend on the synthesis of a macromolecular inhibitor that interferes with coupling of the receptor to the catalytic component of adenylyl cyclase. Bearing in mind the fluidity of the cell membrane, more sophisticated mechanisms may have to be considered: thus it has recently been shown with regard to the acetylcholine receptor of differentiating

Table 8. Inhibition of the desensitizing action of LH on hormone-induced cAMP formation in cultured follicles by actinomycin $D$

\begin{tabular}{lcc}
\hline Initial culture & $\begin{array}{c}\text { Challenge incubation } \\
\text { (with IBMX) }\end{array}$ & $\begin{array}{c}\text { cAMP accumulation } \\
\text { (pmol/follicle) }\end{array}$ \\
\hline Control & Control & $3.6 \pm 0.3$ \\
Control & LH & $170 \pm 13 \cdot 2$ \\
LH $(10 \mu \mathrm{g} / \mathrm{ml})$ & LH & $53.7 \pm 4 \cdot 1$ \\
Actinomycin D $(8.0 \mu \mathrm{m})$ & LH & $172.3 \pm 14.4$ \\
LH + actinomycin D & LH & $136.0 \pm 7.5$ \\
\hline
\end{tabular}

After culture for $9 \mathrm{~h}$ under the conditions shown, the follicles were rinsed and incubated for $30 \mathrm{~min}$ in fresh medium containing $100 \mathrm{mg}$ 3-isobutyl-1-methylxanthine $(\mathrm{IBMX}) / \mathrm{ml}$ and $10 \mu \mathrm{g} \mathrm{LH} / \mathrm{ml}$ as indicated. Values are mean \pm S.E.M. $(n=12)$. From Lamprecht et al. (1977). 
muscle that movement and redistribution of receptors over the cell surface, rather than mere number of binding sites, can be of crucial functional significance (Prives, Silman \& Amsterdam, 1976).

What might be the physiological significance of the desensitization phenomenon? Firstly, it should be borne in mind that it is elicited only at high LH concentrations, approaching the maximally effective level of the hormone. These are unlikely to be attained during tonic gonadotrophin secretion, so that the latter is able to maintain a sustained steroidogenic or follicular growth response. The pulsatile nature of this gonadotrophin secretion would also preclude the development of refractoriness. The preovulatory surge of $\mathrm{LH}$, on the other hand, results in a striking rise in follicular cyclic AMP production (Lindner et al., 1974a), triggering processes dependent on high cyclic AMP concentration (e.g. release of the oocyte from meiotic arrest? See Tsafriri et al., 1972). This would be followed by a phase of suppressed adenylyl cyclase activity, probably responsible for the temporary shut-down of steroid synthesis at ovulation (Hilliard, Scaramuzzi, Pang, Penardi \& Sawyer, 1974), and possibly permitting the initiation of processes independent of cyclic AMP or even suppressed by this nucleotide. The latter processes remain to be identified. Finally, if the $\mathrm{LH}$ surge depends on a 'positive feedback' mechanism, as is often asserted, some quenching device would normally be required to prevent a runaway effect. This could be provided by desensitization of the follicle to LH and/or by an LH-induced shift in the steroidogenic pattern of the follicle from oestrogen to progesterone production (Lindner et al., 1974a).

\section{Determinants of oocytic response to the meiosis-inducing action of gonadotrophins}

The triggering of the maturation division of the mammalian oocyte has been studied in two dissimilar systems in vitro. In the Pincus \& Enzmann (1935) model, the oocyte is dislodged from the follicle and placed in a hormone-free culture medium. The other model consists of intact follicles explanted before the preovulatory gonadotrophin surge into organ culture, so that the normal relationship between the oocyte and the other cellular components of the follicle is preserved (Tsafriri, Lindner \& Zor, 1971; Lindner et al., 1974a). It is instructive to compare the behaviour of these two models. The liberated or denuded oocyte of many species (Edwards, 1965; Mukherjee, 1972) escapes meiotic arrest and proceeds to metaphase II in vitro, without any requirement for added hormones, a striking departure from ovum maturation in vivo which is clearly dependent on gonadotrophic stimulation. By contrast, the follicle-enclosed oocyte, provided it is explanted before the endogenous gonadotrophin surge, persists in the dictyate state unless a suitable hormone is added to the medium. Resumption of meiosis can be triggered in this system by LH, immunochemically pure FSH, or by PGE-2, all of which induce an immediate rise in cyclic AMP accumulation in the follicle (Lindner $e t$ al., 1974a). Exogenous dibutyryl cyclic AMP will also induce ovum maturation, though somewhat less efficiently, if introduced directly into the follicular antrum (Tsafriri et al., 1972). By contrast, the spontaneous maturation of denuded oocytes in culture is delayed by addition of cyclic AMP to the medium (Cho, Stern \& Biggers, 1976), suggesting that the meiosis-triggering action of the nucleotide is not exerted directly on the oocyte.

Although PGE-2 can induce maturation in vitro, and steroids have been convincingly implicated in the triggering of ovum maturation in amphibian eggs, inhibitors of prostaglandin synthetase (indomethacin or flufenamate) or of steroidogenesis (cyanoketone or glutethimide) fail to prevent the effect of LH on ovum maturation in cultured follicles (Lindner et al., 1974a). This seems to eliminate these two classes of compounds, whose synthesis in the follicle is stimulated by LH, as essential mediators of the $\mathrm{LH}$ action on maturation of the mammalian oocyte.

Culture of ovarian fragments has been utilized ingeniously to analyse the optimal time interval between PMSG and HCG treatment of immature mice for maturation of the oocyte in vitro (Neal \& Baker, 1973; Baker, 1974). A significant finding of these studies was that oocytes from small to medium-sized follicles were arrested in culture in metaphase I, i.e. before extrusion of the first polar body, whereas those of large Graafian follicles either reached metaphase II or persisted in the dictyate stage. Contrary to earlier beliefs, the ability of free oocytes to mature spontaneously in vitro also depends on the state of development of the follicle at the time of isolation. Oocytes from pig follicles $<3 \mathrm{~mm}$ in diameter mature less efficiently than those derived from medium-sized or large ( $>6 \mathrm{~mm})$ 
follicles (Tsafriri \& Channing, 1975a), and mouse oocytes acquire the capacity to mature when the follicles are $\geqslant 200 \mu \mathrm{m}$ in diameter (Erickson \& Sorenson, 1974). Hunter, Cook \& Baker (1976) recently made the surprising observation that administration of HCG to pigs on Day 17 of the 21-day oestrous cycle elicits premature ovulation with release of dictyate oocytes, and these fail to lose their germinal vesicles even during subsequent passage through the oviducts.

Studies with ${ }^{125}$ I-labelled HCG have revealed a lack of hormone uptake by small rat follicles, bound radioactivity in these being confined to interstitial cells, and a restriction of hormone binding to the theca in medium-sized follicles, with no labelling of the membrana granulosa (Midgley, 1973; Amsterdam, Koch, Lieberman \& Lindner, 1975a). Small to medium-sized pig follicles, likewise, have few specific HCG-binding sites (Channing \& Kammerman, 1973) and their adenylate cyclase shows very limited responsiveness to LH (Hunzicker-Dunn, 1977) until they approach ovulable size. It seems likely that the striking changes in the biochemical properties of the follicular cells and in the reactivity of the oocyte observed during the final phases of follicle growth are interdependent.

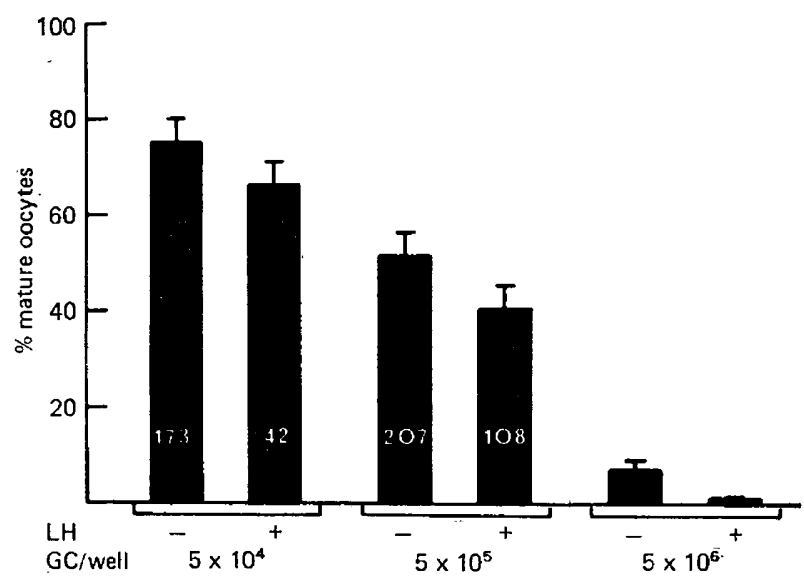

Text-fig. 5. Effect (mean \pm S.E.M.) of granulosa cells upon maturation of porcine oocytes in co-culture. Ten to fifteen oocytes were cultured together with the indicated number of granulosa cells (GC) derived from medium-sized pig follicles (3-5 mm in diameter) in $0.2 \mathrm{ml}$ medium 199 on Falcon Microtest II plates for $43 \mathrm{~h}$. The total number of oocytes scored for the presence of first polar body is indicated in the columns. Results obtained with 0.5 or $5.0 \mu \mathrm{g} \mathrm{LH}(\mathrm{NIH}-\mathrm{S} 19) / \mathrm{ml}$ did not differ significantly and were pooled. Data from Tsafriri \& Channing (1975b).

The contrasting behaviour of isolated and follicle-enclosed oocytes in culture has led to speculation that the granulosa cells exert a restraining action on the oocyte, maintaining it in the dictyate state. Indeed, porcine granulosa cells co-cultured with oocytes inhibit germinal vesicle breakdown in a dose-dependent manner (Text-fig. 5), confirming and extending earlier results by Foote $\&$ Thibault (1969). This inhibition, however, was not reversible by LH. It was further shown that inhibition of the maturation of isolated oocytes does not depend on direct contact with the granulosa cells, but may be transmitted by the follicular fluid or by a factor (FFI) partly purified from porcine follicular fluid and characterized as a peptide of molecular weight $<2000$ (Tsafriri, Pomerantz \& Channing, 1976b). In our laboratory, oocytes from immature rats treated with PMSG at the age of 26 days have been shown to be susceptible to this inhibitory action of porcine FFI, but their sensitivity to the inhibitor depended on the state of follicular development at the time the oocytes were isolated: oocytes harvested $40 \mathrm{~h}$ after administration of the hormone were relatively resistant to porcine follicular fluid or purified FFI, while resumption of meiosis was significantly inhibited in oocytes isolated $20 \mathrm{~h}$ after PMSG treatment (Table 9). The latter inhibition was partly reversed by ovine LH (Table 9), although even in the presence of LH germinal vesicle breakdown was delayed beyond the 6-h period sufficient for its completion in the absence of the inhibitor. 
Table 9. Effect of developmental stage on susceptibility of rat oocytes to a maturation-inhibiting factor from porcine follicular fluid and its reversal by ovine $\mathbf{L H}$

\begin{tabular}{ccccc}
\hline \multicolumn{2}{c}{ Oocytes tested } & & & \\
\cline { 1 - 1 } $\begin{array}{c}\text { Time after } \\
\text { PMSG (h) }\end{array}$ & No. & $\begin{array}{c}\text { Inhibitor } \\
\text { (mg protein/ml) }\end{array}$ & $\begin{array}{c}\text { LH } \\
(\mu \mathrm{g} / \mathrm{ml})\end{array}$ & $\begin{array}{c}\text { Mature oocytes } \\
\%\end{array}$ \\
\hline \multirow{2}{*}{44} & 575 & - & - & 84 \\
& 124 & 0.57 & - & 75 (N.S.) \\
20 & 359 & - & - & 72 \\
& 98 & - & 5 & 83 \\
& 365 & 0.23 & - & $30^{*}$ \\
& 182 & 0.23 & 5 & $57 \dagger$ \\
& 124 & 0.11 & - & $32^{*}$ \\
& 92 & 0.11 & 5 & $70^{\dagger}$ \\
\hline
\end{tabular}

Immature rats (26 days old) received 15 i.u. PMSG s.c. and oocytes with adherent cumulus cells were isolated after the interval indicated and cultured for $20-24 \mathrm{~h}$ with or without the purified inhibitor described by Tsafriri et al. (1976b).

N.S., no significant inhibition; *significant inhibition $(P<0.001)$; $\dagger$ significant reversal of inhibition. Unpublished observations of $A$. Tsafriri, S. H. Pomerantz \& C. P. Channing.

These observations confirm that the action of the inhibitor in porcine follicular fluid is not confined to that species; a similar inhibitory action of follicular fluid has also been observed with rabbit, mouse and hamster eggs in vitro (Chang, 1955; Gwatkin \& Andersen, 1976; Channing \& Tsafriri, 1977). Whether this inhibitor has a physiological role in maintaining meiotic arrest remains to be critically established. It may merely correct a deficiency or departure from physiological conditions inherent in the Pincus-Enzmann culture system which is responsible for the nonhormonal triggering of meiosis in the isolated oocytes, or prevent the meiotic response of the oocyte to a non-physiological insult. The fact that the action of FFI can be neutralized by LH under certain conditions in vitro is of interest, but does not provide unequivocal evidence for its physiological role as a meiosis inhibitor, since again it may merely restore culture conditions under which LH can express its action (see Biggers \& Powers, 1977). Further analysis of the behaviour of oocytes in co-culture with other constituents of the follicle may help to define the role of different follicular factors in the control of oocyte maturation more clearly. Meanwhile, the altered sensitivity of the isolated oocyte to FFI described here (Table 9) provides evidence that the oocyte itself and/or the adjacent cumulus cells undergo important developmental changes during the $36 \mathrm{~h}$ preceding ovulation which modify the propensity of the oocyte to resume its meiotic division.

\section{Distribution of $L H$ receptors and intercellular communication in the preovulatory follicle}

When intact rat follicles, isolated on the morning of pro-oestrus, are briefly exposed to $\mathrm{LH}$ (15-30 $\mathrm{min}$ ), they become irrevocably committed to complete their maturation division upon subsequent culture for $15 \mathrm{~h}$ in hormone-free medium. In vivo, a similar irreversible commitment ensues shortly after the onset of the pro-oestrous gonadotrophin surge (Lindner et al., 1974a). It was therefore of interest to examine the distribution of LH-binding sites in preovulatory follicles. Nembutalblocked pro-oestrous rats were given an i.v. ovulatory dose of radiolabelled HCG, which has high affinity for the rat LH receptor (Koch et al., 1974), and the follicles were examined by autoradiography $3 \mathrm{~h}$ later, i.e. at a time when the hormone-induced commitment to ovum maturation was known to be complete (Amsterdam et al., 1975a). In large preovulatory follicles the granulosa and theca interna cells were labelled (Pl. 1, Fig. 1). However, the distribution of the hormone in the membrana granulosa was non-homogeneous: labelling was intense in the mural granulosa adjacent to the basement membrane (4-5 cell layers), but ten times lower in the periantral granulosa cells (Table 10). More 
Table 10. Distribution of autoradiographic grains over various compartments of the Graafian follicle after administration of ${ }^{125}$ I-labelled HCG

\begin{tabular}{lr}
\hline \multicolumn{1}{c}{ Region of follicle } & $\begin{array}{c}\text { *Silver } \\
\text { grains/1000 } \mathrm{\mu m}^{2}\end{array}$ \\
\hline Theca externa & $5 \cdot 2 \pm 1 \cdot 3$ \\
Theca interna & $37 \cdot 6 \pm 4 \cdot 2$ \\
Mural granulosa cells $\dagger$ & \\
(a) Adjacent to basement membrane & $26.2 \pm 3 \cdot 2$ \\
(b) Intermediate layer & $7 \cdot 0 \pm 1 \cdot 0$ \\
(c) Periantral layer & $2 \cdot 3 \pm 0.3$ \\
Follicular antrum & $2 \cdot 7 \pm 0.3$ \\
Cumulus oophorus & $1.4 \pm 0.2$ \\
Zona pellucida & $2.9 \pm 1 \cdot 2$ \\
Oocyte & $1 \cdot 1 \pm 0.3$ \\
Parts of section devoid of tissue & $1.4 \pm 0.2$ \\
\hline
\end{tabular}

* Mean value \pm S.E.M. for 5 follicles. Total number of grains counted was 3480 (30-1440 per region). Sections coated with G5 emulsion were exposed for 25 days.

$\dagger$ Mural granulosa was divided into three concentric regions: (a) cells within $45 \mu \mathrm{m}$ of the basement membrane (4 layers of cells); (b) cells $45-90 \mu \mathrm{m}$ from the basement membrane; and (c) the remaining cells bounding the follicular antrum.

(From Amsterdam et al., 1975a.)

\section{EXPLANATION OF PLATES}

\section{PLATE 1}

Figs 1 and 2. Autoradiograph of preovulatory rat follicle $3 \mathrm{~h}$ after in-vivo administration of ${ }^{125} \mathrm{I}$-labelled HCG, showing the follicular wall (Fig. 1) and the cumulus oophorus (Fig. 2). Note the high density of silver grains over the theca interna ( $\mathrm{Ti}$ ) and 3-4 outer layers of granulosa cells $(\mathrm{G})$ and the scarcity of grains over the oocyte $(O)$ and cumulus. Bc, blood capillaries; $A$, antrum; $\mathrm{Cr}$, corona radiata; $\mathrm{Zp}$, zona pellucida; $\mathrm{Nu}$, nucleolus of germinal vesicle. (Reproduced by permission from Amsterdam et al., 1975a.)

Figs 3,4 and 5. Cryostat sections of the walls of large follicles from 20-week-old rats (unpublished work of A. Amsterdam, H. R. Lindner \& U. Gröschel-Stewart). Fig. 3. Section treated with antibodies to chick gizzard myosin and fluorescein-labelled anti-rabbit $\gamma$-globulin; incident u.v. light. Note the fluorescent girdle in the theca externa (Te) consisting of about 6 layers of intensely stained cells. The circumferences of the granulosa $(\mathrm{G})$ and theca interna (Ti) cells are faintly stained. Fig. 4. Section stained with haematoxylin and eosin; transmitted visible light. Theca externa consists of 6-8 layers of elongated cells orientated parallel with the circumference of the follicle. Fig. 5. Section stained by indirect fluorescence with antibodies to avian pectoral muscle actin. The distribution of fluorescence closely corresponds to that obtained with antibodies to gizzard myosin (see Fig. 3). $\times 320$.

PLATE 2

Fig. 6. Large gap junction of granulosa cell from preovulatory follicle; replica of freeze-fractured preparation showing the A face. Intramembrane particles form a mosaic of clusters. Individual clusters consist of a hexagonal lattice with particle-to-particle spacing of 9-10 $\mathrm{nm}$, revealed by the optical diffractogram (insert $\left.b^{\prime}\right)$. The diffraction pattern derived from the entire junctional area is ring-shaped, indicating random orientation of the component lattices $\left(\mathrm{a}^{\prime}\right) . \times 67,800$.

Fig. 7. Replica of freeze-cleaved annular junction (AG). Intramembrane particles are arranged in clusters or bands yielding hexagonal diffraction patterns similar to gap junctions (insert derived from framed area $c$ ). $\times 54,400$. (Reproduced by permission from Amsterdam et al., 1976.)

Fig. 8. Gap junction (arrow) in area of contact between oocyte (o) and cytoplasmic process (cp) of corona cell penetrating the zona pellucida. $\mathrm{cg}$, cortical granule. Thin section photographed at a tilting angle of $18^{\circ}$ to the optical axis. $\times 39,000$. At higher magnification (inset, $\times 115,000$ ) the junction appears as a pentalaminar structure about $18 \mathrm{~nm}$ thick. 
PIATE: 1
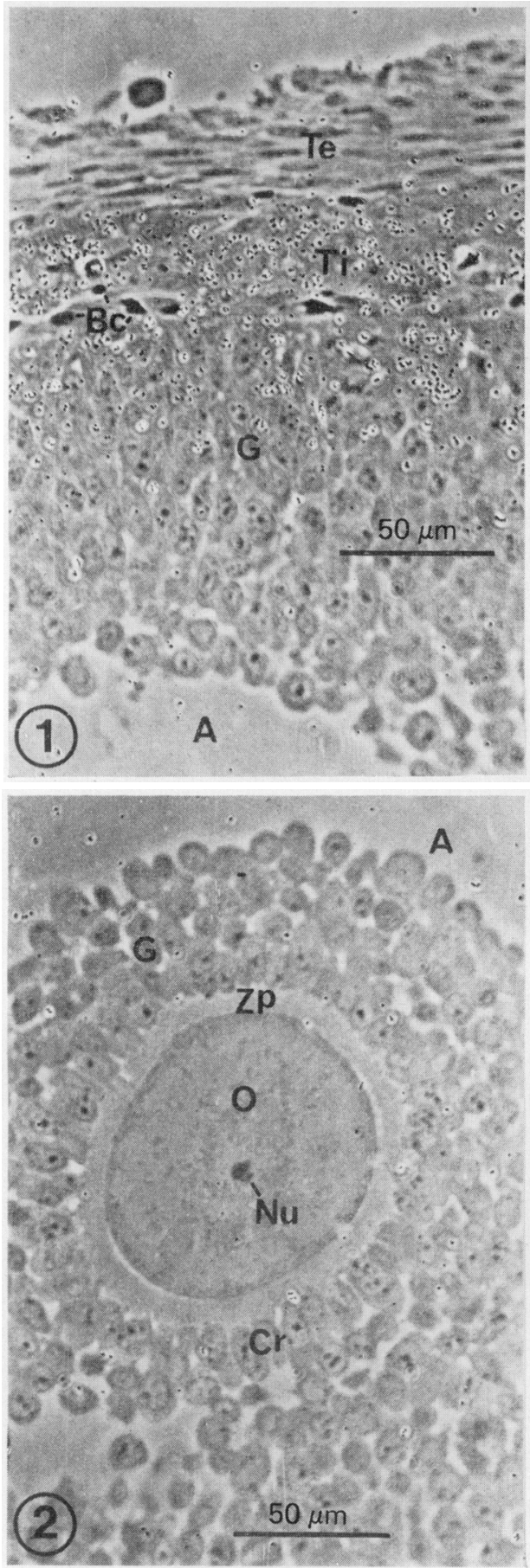
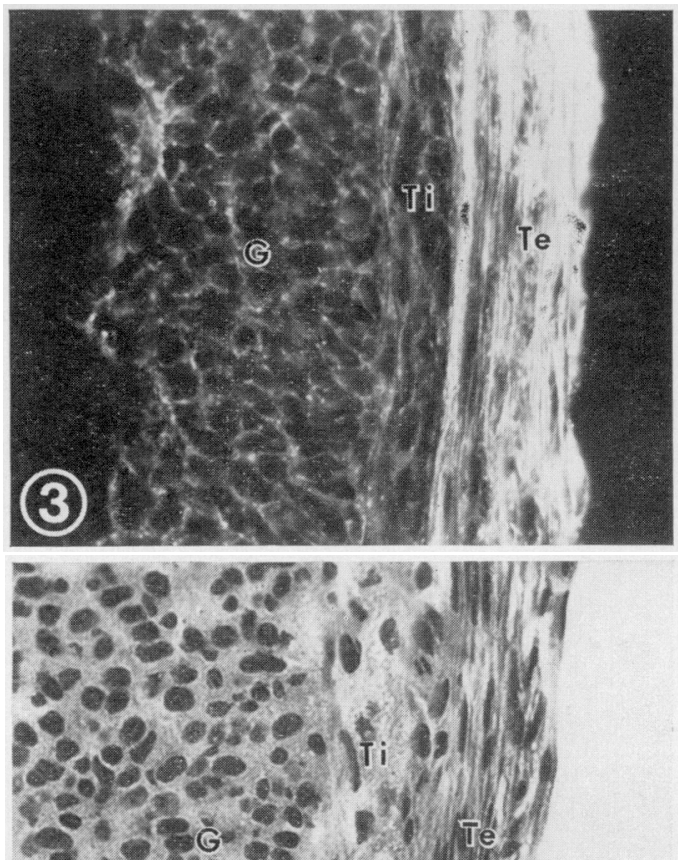

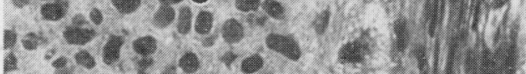

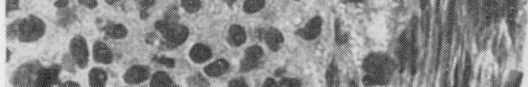

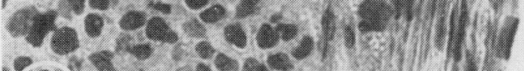

intin

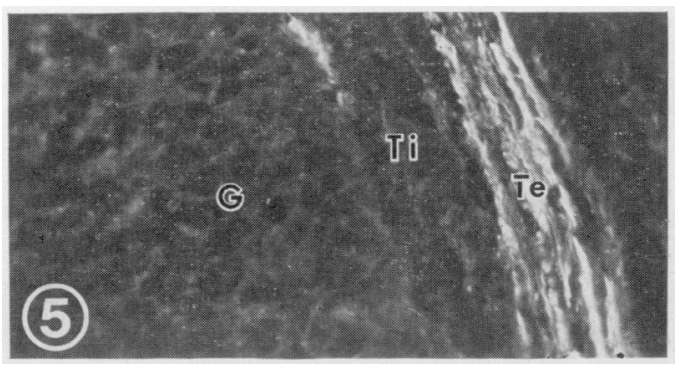



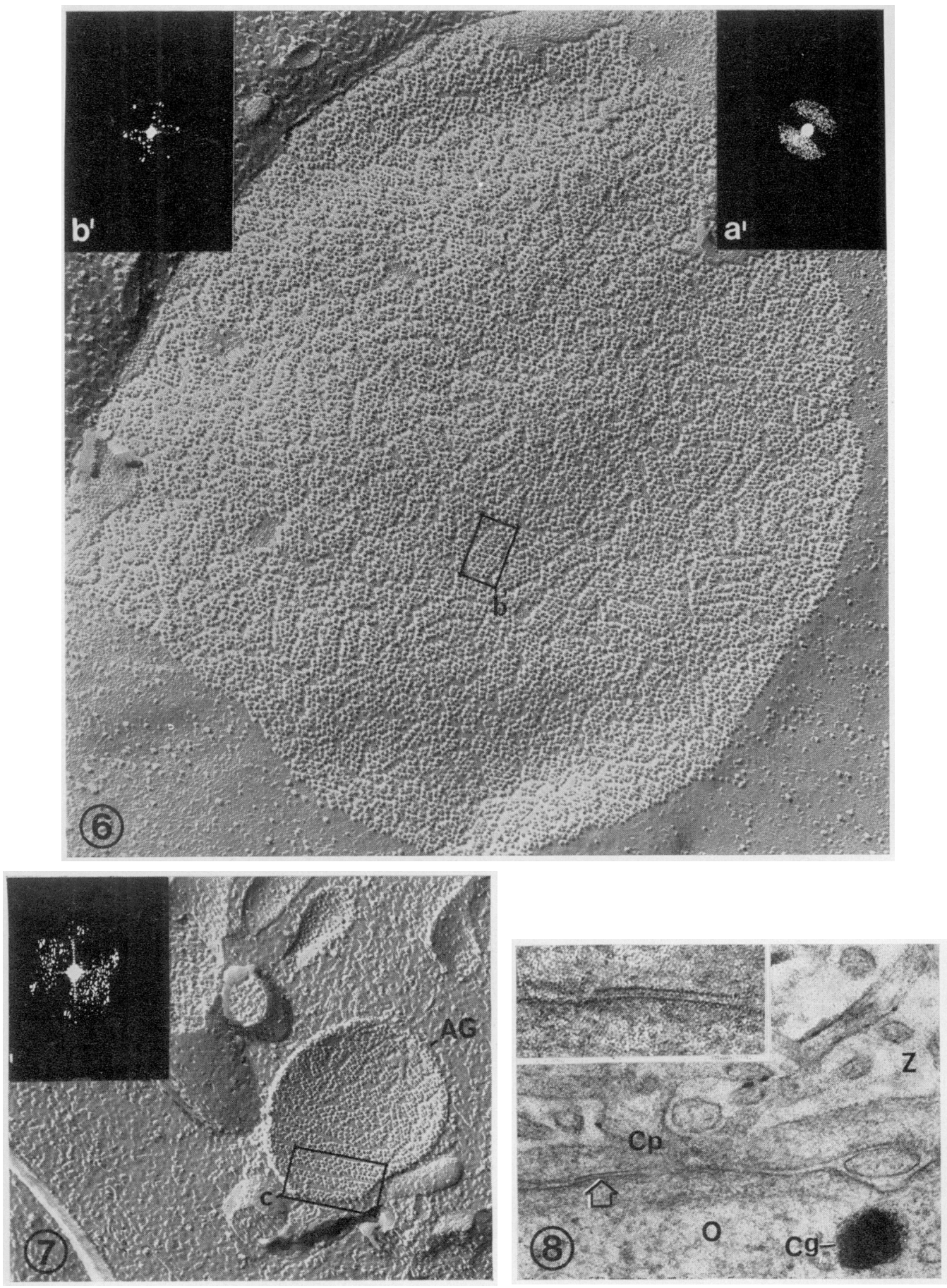
PLATE 3
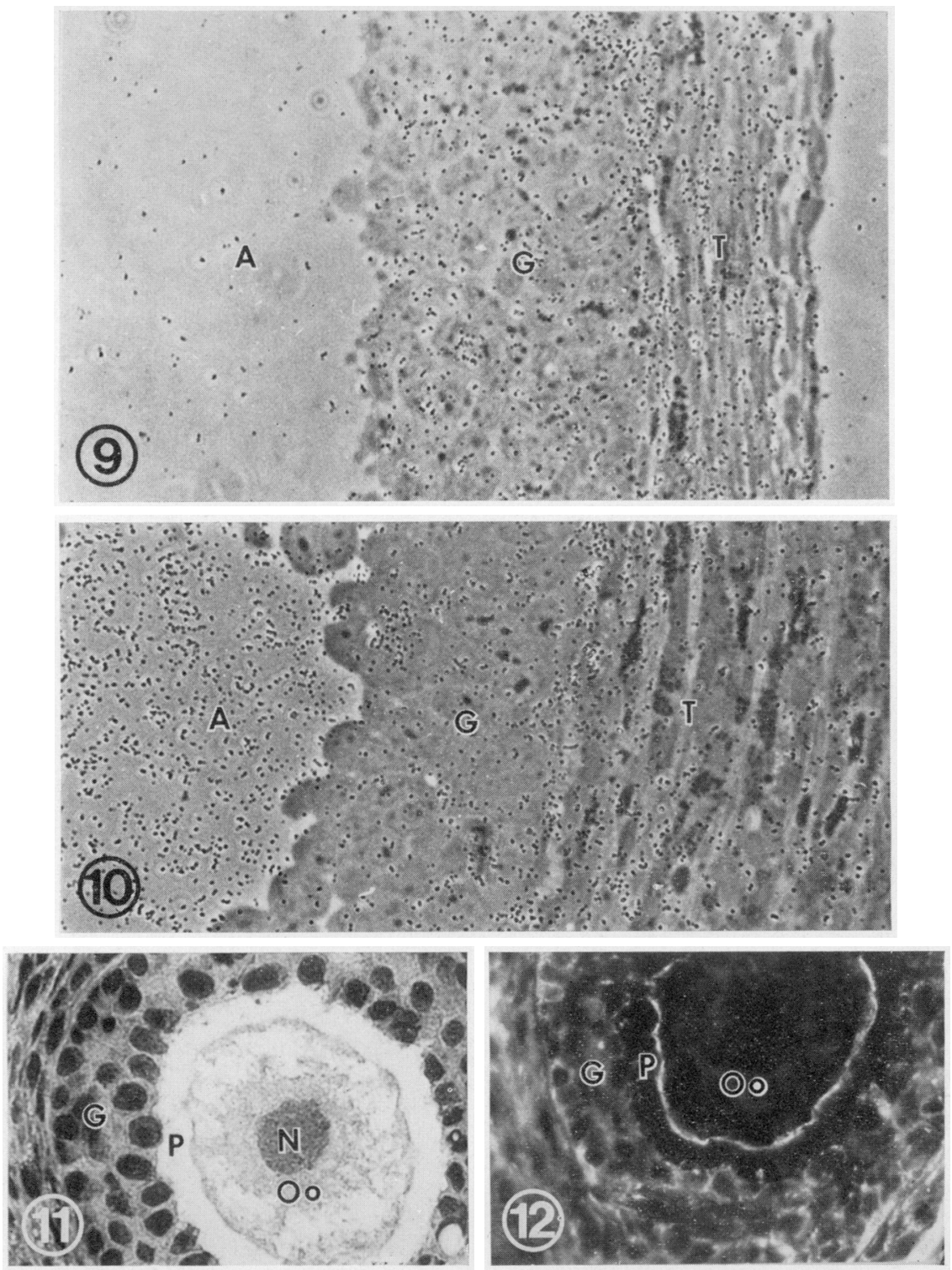

Figs 9 and 10. Micro-autoradiograms of ovarian tissue slices from 20-week-old rats pulse-labelled in vitro for $10 \mathrm{~min}$ with ${ }^{35} \mathrm{SO}_{4}$, followed by a cold $\mathrm{MgSO}_{4}$ chase. Immediately after the pulse, thecal (T) and granulosa (G) cells of antral follicles were highly labelled (Fig. 9), while labelling of the antrum (A) did not exceed background. By 30 min after the onset of the pulse the antrum was intensely labelled (Fig. 10).

Figs 11 and 12. Cryostat sections (umpublished observations of A. Amsterdam, H. R. Lindner \& U. Gröschel-Stewart) of preantral follicles from 20-day-old rats stained with haematoxylin and eosin (Fig. 11) and antibodies to avian (gizzard) myosin, by the indirect fluorescence method (Fig. 12). A fluorescent band beneath the zona pellucida delineates the circumference of the oocyte in sections treated with anti-gizzard myosin or anti-actin (not shown), but not in controls treated with normal rabbit $\hat{i}$-globulins (not shown). N. germinal vesicle: Oo, oocyte: P. zona pellucida: G, granulosa cells. $\times 400$. 
surprisingly, no significant concentration of autoradiographic grains above background was demonstrable over the cumulus cells and oocyte (Pl. 1, Fig. 2), although the oocyte responds to the hormone under similar experimental conditions with resumption of its meiotic division. This suggested the existence of an intercellular communication system permitting the propagation of the hormonal stimulus beyond the cells rich in hormone receptor to the interior of the follicle.

A possible anatomical basis for such intercellular communication was provided by the demonstration of extensive gap junctions, best visualized in freeze-cleaved preparations (Pl. 2, Fig. 6) between cells within the theca interna, the granulosa layer, and perhaps most significantly, between cytoplasmic extensions of corona cells traversing the zona pellucida and the oolemma (Pl. 2, Fig. 8) (Albertini \& Anderson, 1974; Amsterdam, Josephs, Lieberman, and Lindner, 1974, 1976). These specialized cell junctions have been shown in other tissues to be highly permeable to ions and to small molecules comparable in size to cyclic AMP (Sheridan, 1971; Azarnia, Larsen \& Loewenstein, 1974). Cyclic AMP has been implicated in the triggering of ovum maturation, although its action is unlikely to be a direct one on the oocyte (see above). However, the gap junctions may provide a gateway for other chemical messages, inhibitory or stimulatory, to the oocyte. Furthermore, the high permeability of gap junctions to ions results in electrical coupling of neighbouring cells (Sheridan, 1971; Azarnia et al., 1974). To demonstrate such coupling between the mammalian oocyte and cumulus cells presents formidable technical difficulties, but a preliminary report (N. B. Gilula, personal communication) suggests that it does in fact occur. This may be a very important issue, because the maturation of the oocyte in many non-vertebrates, e.g. starfish (Tyler, Monroy, Kao \& Grundfest, 1956), is associated with, and perhaps dependent upon, a drastic reduction in its membrane potential (reviewed by Biggers \& Powers, 1977). This crucial step may be prevented while the oocyte is electrically coupled to the surrounding cumulus cells. Preliminary observations suggest that the LH surge is followed by a reduced incidence of gap junctions in the membrana granulosa, some of which may be internalized to appear as 'annular junctions' (PI. 2, Fig. 7). An LH-induced dismantling of gap junctions linking the oocyte to coronal cells could permit the oocyte to undergo the requisite changes in membrane potential, or to escape from the influence of metabolic inhibitors within the follicle, and resume meiosis. Such a hormone-induced sequestration of the oocyte might be analogous to that brought about by surgical isolation of the oocyte in the Pincus-Enzmann system. Some of the apparent inconsistencies between the results of different test systems used to study the meiotic response may thus eventually be resolved. Meanwhile, the hormonal induction of ovum maturation remains a challenging problem.

\section{Modulation of gonadotrophin action by prostaglandins}

It is now established beyond doubt that prostaglandins of the $\mathrm{E}$ and $\mathrm{F}$ group are synthesized within the follicle in the rat and rabbit ovary, and that their production is stimulated by LH in vivo as well as in isolated cultured follicles. References to the extensive literature from several laboratories are cited by Bauminger \& Lindner (1975). This stimulatory action of LH is not dependent on steroid synthesis (Bauminger, Lieberman \& Lindner, 1975), but can be simulated by cyclic AMP and-with less efficacy - by cyclic GMP (U. Zor, unpublished observations). PGE-2 can mimic many of the actions of $\mathrm{LH}$ on the rat follicle, including the stimulation of cyclic AMP accumulation, steroidogenesis, ornithine decarboxylase activity, and the triggering of ovum maturation in vitro and of ovulation in vivo. The role of prostaglandins in these responses has recently been reviewed (Lindner et al., 1974b; Goldberg \& Ramwell, 1975; Zor \& Lamprecht, 1977). While the actions of LH are likely to be reinforced by local PG synthesis, which is augmented in the wake of the gonadotrophin surge with a delay of 2-4 h, most of them (ovum maturation, activation of adenylyl cyclase, steroidogenesis and luteinization) will proceed while PG synthesis is inhibited by drugs. The exception is follicular rupture, which is prevented by administration of indomethacin. This treatment does not abolish the LH surge in the rat, indicating that the effect is exerted at the level of the ovary. The indomethacin block is reversible by exogenous PGE-2. Another drug, $\Delta^{1}$-tetrahydrocannabinol, the active ingredient of marihuana, blocks ovulation by preventing pro-oestrous LH-RH secretion, but also reduces the oyarian sensitivity to the ovulatory action of exogenous LH (Nir, Ayalon, Tsafriri, 
Cordova \& Lindner, 1973; Ayalon et al., 1977): a 4-fold dose of LH is required in such animals $(10 \mu \mathrm{g} / \mathrm{rat})$ compared with the minimal effective dose in Nembutal-blocked rats $(2.5 \mu \mathrm{g} / \mathrm{rat})$. The impeded ovarian response to LH could be attributed to inhibition of ovarian PG synthesis by $\Delta^{\mathbf{1}}$ tetrahydrocannabinol.

\section{Actin and myosin in the external theca and the role of prostaglandins in the extrusion of the oocyte}

The precise nature of PG involvement in the process of follicular rupture remains obscure. In the search of a plausible target for this PG action, we examined the distribution of actin and myosin in the follicle wall, because PGs are known to influence smooth muscle function (Sammer, Rosek \& Cammarata, 1968), probably by modulating sympathetic neuromuscular transmission. The existence of non-vascular adrenergic nerve terminals in follicles has been reported (Jacobowitz \& Wallach, 1967; Walles et al., 1974, 1975).

In collaborative work with Dr Gröschel-Stewart, rat follicles were sequentially treated with specific antisera to smooth-muscle (chicken gizzard) myosin or chicken (pectoral muscle) actin and with fluoresceinated anti $\gamma$-globulin (Amsterdam, Lindner \& Gröschel-Stewart, 1975b, 1977). Fluorescent microscopy of serial sections revealed that the external theca contained several layers of elongated cells reacting intensely with both anti-actin and anti-smooth muscle myosin (Pl. 1, Figs 3 and 5), while showing no reaction to normal rabbit serum or antiserum to striated muscle myosin. These cells formed an interwoven basket around the larger follicles and interrupted fluorescent streaks around smaller ones, but were absent in stage 3 (Pedersen, 1970) follicles of 6-day-old rats. The thecal cells of mature Graafian follicles are rich in microfilaments (6 nm in diameter) and the follicle wall is capable of a contractile response to gonadotrophins (Coutinho \& Maia, 1972) and to sympathomimetic amines (Virtumasen, Wright \& Wallach, 1972).

Taken together, these findings justify the classification of the theca externa cells as smooth muscle cells. The appearance of contractile elements in the theca late in follicular development represents one of the rare examples of post-natal muscle differentiation. They may play a part in the mechanical response of the follicular wall to $\mathrm{LH}$, an $\mathrm{LH}$ effect conceivably mediated by PGs and/or adrenergic nerve terminals. Thecal contractions could be responsible for the rhythmic changes in intrafollicular pressure observed by Coutinho \& Maia (1972) in man, and for the rapid extrusion of the cumulus mass at ovulation. Measurable intrafollicular pressure changes during ovulation have been denied, but may well be prevented by the increased distensibility of the follicular wall at that time. This weakening of the follicular wall has been attributed to the action of progesterone (Rondell, 1970) and to the induction or activation of proteolytic enzymes (Beers, Strickland \& Reich, 1975; Espey \& Coons, 1976). The nature of these enzymes, the manner of their activation and their relation, if any, to PGs is still a matter of controversy. PGF- $2 \alpha$ has recently been shown to cause release of cathepsin D from lysozomes in the corpora lutea of pregnant rats (unpublished observations).

\section{Actin and myosin in the oocyte}

Evidence has also been obtained for the presence of actin and smooth-muscle myosin in the rat oocyte. Immunofluorescence induced with antisera to these two proteins was confined to a layer beneath the zona pellucida, probably associated with the oolemma (P1. 3, Figs 11 and 12). Actin and myosin have been identified in the eggs of non-vertebrates (Perry, John \& Thomas, 1971; Kane, 1975; Mabuchi, 1976). While these proteins may have more obvious functions during the post-fertilization and cleavage phases of zygote development, a role in the response to $\mathrm{LH}$ is also possible, e.g. in spindle rotation, abstriction of the first polar body, and in the formation of the perivitelline space.

\section{Gonadotrophins and acid mucopolysaccharide accumulation in antral fluid}

A crucial stage in follicular development is the formation of a fluid-filled antrum, an FSHdependent process. Investigations carried out in the 1950s (Odeblad \& Boström, 1953; Jensen \& Zachariae, 1958) established the presence of acid mucopolysaccharides in the follicular fluid and pointed to a possible role of these substances in the regulation of intrafollicular pressure (Zachariae, 
1959). Abnormal accumulation of acid mucopolysaccharides occurs in the ovaries of thyroiddeficient experimental animals (Thorsøe, 1962) and may or may not be relevant to ovulatory failure. in hypothyroid women (Edwards, Forsyth \& Besser, 1971). The significance of these follicular fluid constituents thus seemed to deserve further investigation.

We have shown (Gebauer, Koch, Lindner \& Amsterdam, 1976 and unpublished observations) that ovarian slices incorporated ${ }^{35} \mathrm{SO}_{4}$ into sulphated glycosaminoglycans (S-GAG) consisting of chondroitin-4-sulphate and 6-sulphate (together about $15 \%$ ), dermatan sulphate ( $25 \%$ ) and heparinlike substances (ca. 60\%), including a small amount of heparin. Pulse-chase experiments and autoradiography showed that ${ }^{35} \mathrm{SO}_{4}$ incorporation took place in thecal and granulosa cells, but labelled S-GAGs were secreted within $30 \mathrm{~min}$ of the beginning of a 10-min pulse into the antral fluid, and after $4 \mathrm{~h}$ their concentration in the fluid exceeded that in the cells (Pl. 3, Figs 9 and 10). Preantral follicles were poorly labelled, suggesting a possible dependence on FSH secretion, but this point has not been critically examined. On the other hand, preincubation of slices with $\mathrm{LH}(10 \mu \mathrm{g} / \mathrm{ml})$ for $6 \mathrm{~h}$ markedly inhibited $\mathrm{SO}_{4}$ incorporation; even more profound inhibition $(80 \%)$ was produced by progesterone. The steroid effect has a shorter latency $(2 \mathrm{~h})$, suggesting that the LH effect may be mediated by progesterone: $\mathrm{LH}$ causes a more than 10 -fold increase in progesterone accumulation in cultured follicles within $4 \mathrm{~h}$ (Lindner et al., 1974a).

The occurrence of heparin in follicular fluid, though in small amounts, and the hormone-induced changes in its concentrations are of particular interest, because of the many biological actions of this class of compounds. R. H. F. Hunter (personal communication) has observed that spontaneous coagulability of porcine follicular fluid increases sharply as the follicle approaches ovulation. Besides its anticoagulant action, heparin has been reported to have antimitotic properties (Kaye, 1956) and to inhibit protein synthesis (Waldman \& Goldstein, 1973). Since the effects of LH on ovum maturation and follicular steroidogenesis depend on de-novo protein synthesis (Lieberman et al., 1975) and luteinization of the follicle involves cell proliferation, a regulatory function of the heparinlike substances in antral fluid in relation to these gonadotrophin responses cannot be excluded at this stage.

\section{Concluding remarks}

Molecular endocrinology has been preoccupied for some time with the primary events of hormone action. The questions asked related to what happens early, preferably within minutes or seconds, after the hormone interacts with its specific receptor. This approach has yielded worthwhile dividends, but so far has failed to reveal how a precisely programmed developmental sequence might be achieved. But it is the control of such temporal sequences of developmental events that is the crux of ovarian physiology. Recent insights into delayed effects of hormones on the sensitivity of their targets to the same hormone or to other agents may help provide a conceptual framework for mechanistic analysis of developmental sequences of this kind in the ovary. Relevant phenomena-at the ovarian level-include heterologous receptor induction (see Richards \& Midgley, 1976), refractoriness of adenylyl cyclase to continued hormonal stimulation, synergistic and antagonistic interactions between protein and steroid hormones, and perhaps redistribution of receptors on the cell membrane.

Ultimately, one would like to understand in molecular terms what distinguishes the follicle that has joined the limited set of growing follicles from the multitude of resting follicles, and what makes this 'cohort' enter a final spurt of accelerated growth that will end for most of its members in atresia but culminates for the lucky, or selected, few in ovulation. We are far from such understanding. Is there a meaningful selection process at work ? Is the follicle constrained during early development to follow a predetermined 'production line', as suggested by Henderson \& Edwards (1968) ? Or does the ovary after all just "play dice", as implied by the probabilistic model proposed by Edwards et al. (1977)?

I am grateful to my colleagues Dr H. Gebauer, Dr U. Gröschel-Stewart and Dr M. Lahav for permission to quote unpublished material. The work was supported by the Ford Foundation and the 
Population Council Inc., New York. This review was written during the tenure by H.R.L. of a Royal Society/Israel Academy Visiting Research Professorship in the laboratory of Professor R. V. Short, F.R.S., Medical Research Council Unit for Reproductive Biology, Edinburgh, U.K.

\section{References}

Ahrén, K., Herlitz, h., Nilsson, L., Perklev, T., Rosberg, S. \& Selstam, G. (1974) Gonadotropins and cyclic AMP in various compartments of the rat ovary. In Gonadotropins and Gonadal Function, pp. 364-375. Ed. R. A. Moudgal. Academic Press, New York.

AlberTini, D.F. \& ANDERson, E. (1974) The appearance and structure of intercellular connections during the ontogeny of the rabbit ovarian follicle with particular reference to gap junctions. J. Cell Biol. 63, 234250.

Amsterdam, A., Josephs, R., Lieberman, M.E. \& LINDNER, H.R. (1974) Organization of intramembrane particles of granulosa cell gap junctions in rat ovarian follicles. J. Cell Biol. 63, 8a.

Amsterdam, A., Косh, Y., Lieberman, M.E. \& LINDNER, H.R. (1975a) Distribution of binding sites for human chorionic gonadotrophin in the preovulatory follicle of the rat. J. Cell. Biol. 67, 894-900.

AMSTERDAM, A., LINDNER, H.R. \& GröSCHel-STEWART, U. (1975b) Immunofluorescent localization of actin and myosin in the rat ovary. J. Cell Biol. 67, 8a.

Amsterdam, A., Josephs, R., LIEBerman, M.E. \& LINDNER, H.R. (1976) Organization of intramembrane particles in freeze-cleaved gap junctions of rat Graafian follicles: optical diffraction analysis. J. Cell Sci. 21, 93-105.

AmSterdam, A., LindNer, H.R. \& Gröschel-Stewart, U. (1977). Localization of actin and myosin in the rat oocyte and follicular wall by immunofluorescence. Anat. Rec. 187, 311-327.

Ayalon, D., Cordova, T., Bauminger, S., Puder, M., NAOR, Z., Nir, I., Kashi, R., Zor, U., HARell, A. \& LINDNER, H.R. (1977) Acute effect of $\Delta^{1}$-tetrahydrocannabinol on the hypothalamo-pituitaryovarian axis in the rat. Neuroendocrinology (in press).

Azarnia, R., LARSEN, W.J. \& Loewenstein, W.R. (1974) The membrane junctions in communicating and non-communicating cells, their hybrids, and segregants. Proc. natn. Acad. Sci. U.S.A. 71, 880884.

BAKER, T.G. (1974) Gonadotropin action on cultural follicles. (Discussion section.) Recent Prog. Horm. Res. 30, 127-129.

Bauminger, S. \& Lindner, H.R. (1975) Periovulatory changes in ovarian prostaglandin formation and their hormonal control. Prostaglandins 9, 737-751.

Bauminger, S., Lieberman, M.E. \& Lindner, H.R. (1975) Steroid-independent effect of gonadotropins on prostaglandin synthesis in rat Graafian follicles in vitro. Prostaglandins 9, 753-764.

Beers, W.H., Strickland, S. \& Reich, E. (1975) Ovarian plasminogen activator: relationship to ovulation and hormonal regulation. Cell 6, 387-394.
BERGH, C. \& AHRÉN, K. (1976) Drastic prolongation of the effect of LH on ovarian cyclic AMP formation. Proc. Sth Int. Congr. Endocr., Hamburg Abstr. 176, p. 71.

Biggers, J.D. \& Powers, D. (1977) Comments on the control of meiotic maturation. In Ovarian Follicular Development and Function. Eds A. R. Midgley \& W. A. Sadler. Raven Press, New York.

Chang, M.C. (1955) The maturation of rabbit oocytes in culture and their maturation, activation and subsequent development in the fallopian tubes. $J$. exp. Zool. 128, 378-399.

Channing, C.P. \& Kammerman, S. (1973) Characteristics of gonadotrophin receptors of porcine granulosa cells during follicle maturation. Endocrinology 92, 531-540.

Channing, C.P. \& Tsafriri, A. (1977) Regulation of ovulatory processes: ovum maturation, follicular rupture and luteinization. In Advances in Fertility Regulation Through Basic Research. Eds W. A. Sadler \& S. Segal. Plenum Press, New York.

Cho, W.K., STERN, S. \& BIGGers, J.D. (1976) Inhibitory effect of dibutyryl cAMP on mouse oocyte maturation in vitro. J. exp. Zool. 187, 383-386.

CoutinHo, E.M. \& MAIA, H.S. (1972) Effects of gonadotrophins on motility of human ovary. Nature, New Biol. 235, 94-96.

Dorrington, J.H., Moon, Y.S. \& ARmstrong, D.T. (1975). Estradiol-17 $\beta$ biosynthesis in cultured granulosa cells from hypophysectomized immature rats; stimulation by follicle-stimulating hormone. Endocrinology 97, 1328-1330.

EdWARDS, C.R.W., Forsyth, I.A. \& Besser, G.M. (1971). Amenorrhoea, galactorrhoea and primary hypothyroidism with high circulating levels of prolactin. Br. med. J. 3, 462-464.

EDWARDS, R.G. (1965) Maturation in vitro of mouse, sheep, cow, pig, rhesus monkey and human ovary oocytes. Nature, Lond. 208, 349-351.

EDWARDS, R.G., FOWLER, R.E., GoRE-LANGTON, R.E., Gosden, R.G., Jones, E.C., Redhead, C. \& Steptoe, P.C. (1977) Normal and abnormal follicular growth in mammalian ovaries J. Reprod. Fert. 51, 237-263.

ERICKSON, G.F. \& SoreNSON, R.A. (1974) In vitro maturation of mouse oocytes isolated from late, middle and preantral Graafian follicles. J. exp. Zool. 190, 123-127.

EshKol, A. \& LuNENFELd, B. (1972) Gonadotropin regulation of ovarian development in mice during infancy. In Gonadotropins, pp. 335-346, Eds B. B. Saxena, C. G. Beling \& H. M. Gandy. John Wiley \& Sons, Inc., New York.

ESPEY, L.L. \& CoONS, P.J. (1976) Factors which influence ovulatory degradation of rabbit Qvarian follicles. Biol. Reprod. 14, 233-245. 
Foote, W.D. \& Thibault, C. (1969) Recherches expérimentales sur la maturation in vitro des ovocytes de Truie et de Veau. Annls Biol, anim. Biochim. Biophys. 9, 329-349.

Gebauer, H., Koch, Y., Lindner, H.R. \& AmSTERdam, A. (1976) Sulfated glycosaminoglycans in the rat ovary: synthesis affected by $\mathbf{L H}$ and progesterone. Proc. 5th Int. Congr. Endocrinology, Hamburg, Abstr. 811, p. 335.

Goldberg, V.J. \& Ramwell, P.W. (1975) Role of prostaglandins in reproduction. Physiol. Rev. 55, 325-351.

Goldenbern, R.L., Reiter, F.O. \& Ross, G.T. (1973) Follicle response to exogenous gonadotropins: an estrogen-mediated phenomenon. Fert. Steril. 24, 121-125.

Goldman, B.D., Grazia, Y.R., Kamberi, I.A. \& PORTER, J.C. (1971) Serum gonadotropin concentrations in intact and castrated neonatal rats. Endocrinology 88, 771-776.

Gwatkin, R.B.L. \& ANDERSEN, O.F. (1976) Hamster oocyte maturation in vitro-inhibition by follicular components. Proc. 8th A. Meeting, Soc. Study Reprod., Fort Collins, Abstr. 77.

Henderson, S.A. \& Edwards, R.G. (1968) Chiasma frequency and maternal age in mammals. Nature, Lond. 218, 22-28.

Hilliard, J., Scaramuzzi, R.J., Pang, C.-N., Penardi, R. \& SAWYER, C.H. (1974) Testosterone secretion by rabbit ovary in vitro. Endocrinology 94, 267-271.

Hunter, R.H.F., Cook, B. \& Baker, T.G. (1976) Dissociation of response to injected gonadotropin between the Graafian follicle and oocyte in pigs. Nature, Lond. 260, 156-158.

HuNZICKER-DUNN, M. (1977). Hormone action in ovarian follicles. In Ovarian Follicular Development and Function. Eds A. R. Midgley, Jr \& W. A. Sadler. Raven Press, New York.

Hunzicker-DuNN, M. \& Birnbaumer, L. (1975) Physiological aspects of adenylyl cyclase in follicles and corpora lutea of rats. (Proc. 57th A. Meeting, Endocr. Soc.) Endocrinology 96A, Abstr. 110, p. 105.

ICEKSON, I., KAYE, A.M., Lieberman, M.E., LAMPRECHT, S.A., LAHAV, M. \& LINDNER, H.R. (1974) Stimulation by luteinizing hormone of ornithine decarboxylase in rat ovary: preferential response by follicular tissue. $J$. Endocr. 63, 417-418.

JACOBOWITZ, D. \& WALLACH, E.E. (1967) Histochemical and chemical studies of the autonomic innervation of the ovary. Endocrinology 81, 1132-1139.

Jensen, C.E. \& ZaChariae, F. (1958) Studies in the mechanism of ovulation: isolation and analysis of acid mucopolysaccharides in bovine follicular fluid. Acta endocr., Copenh. 27, 356-368.

Kammerman, S., Canfield, R.E., Kolena, J. \& Channing, C.P. (1972) The binding of iodinated hCG to porcine granulosa cells. Endocrinology 91, 65-74.

KANE, R.E. (1975) Preparation and purification of polymerized actin from sea urchin egg extracts. $J$. Cell Biol. 66, 305-315.

KAYE, A.M. (1956) A comparison of antimitotic and anticoagulant activity. Ph.D. thesis, University of Pennsylvania. (Diss. Abstr. 16, 1190.)
KAYE, A.M., ICEkson, I. \& LINDNER, H.R. (1971) Stimulation by estrogens of ornithine and S-adenosyl methionine decarboxylase in the immature rat uterus. Biochim. biophys. Acta 252, 150-159.

KAYE, A.M., ICEKSON, I., LAMPRECHT, S.A., GRuSS, R., TSAFRIRI, A. \& LINDNER, H.R. (1973a) Stimulation of ornithine decarboxylase activity by luteinizing hormone in immature and adult rat ovaries. Biochemistry, N.Y. 12, 3072-3076.

KAYE, A.M., SömJEN, D., KIng, R.J.B., SömJEN, G., ICEKSON, I. \& LINDNER, H.R. (1973b) Sequential gene expression in response to oestradiol- $17 \beta$ during postnatal development. In Control of Gene Expression, pp. 383-402. Eds A. Kohn \& A. Shalkay. Plenum Press, New York.

Koch, Y., Zor, U., Pomerantz, S., Chobsieng, P. \& LINDNER, H.R. (1973) Intrinsic stimulatory action of FSH on ovarian adenylate cyclase. $J$. Endocr. 58, 677-678.

Koch, Y., ZoR, U., Chobsieng, P., LAMPRECht, S.A., Pomerantz, S. \& LiNDNER, H.R. (1974) Binding of luteinizing hormone and human chorionic gonadotrophin to ovarian cells and activation of adenylate cyclase. $J$. Endocr. 61, 179-191.

Kolena, J. \& Channing, C.P. (1972) Stimulatory effects of LH, FSH and prostaglandins upon cyclic 3'5'-AMP levels in porcine granulosa cells. Endocrinology 90, 1543-1550.

Kuo, J. F. \& Greengard, P. (1969) Cyclic nucleotidedependent protein kinases. IV. Widespread occurrence of adenosine $3^{\prime}, 5^{\prime}$-monophosphate-dependent protein kinases in various tissues and phyla of the animal kingdom. Proc. natn. Acad. Sci. U.S.A. 64, 1349-1355.

LAMPRECHT, S.A., Zor, U., TSAFRIRI, A. \& LINDNER, H.R. (1973) Action of prostaglandin $E_{2}$ and of luteinizing hormone on ovarian adenylate cyclase, protein kinase and ornithine decarboxylase activity during postnatal development and maturity in the rat. J. Endocr. 57, 217-233.

LAMPrecht, S.A., KoHEN, F., Ausher, J., Zor, U. \& LINDNER, H.R. (1976a) Hormonal stimulation of oestradiol-17 $\beta$ release from the rat ovary during early postnatal development. J. Endocr. 68, 343-344.

LAMPRecht, S.A., Zor, U., KoCh, Y., SALOMON, Y., Misulovin, Z. \& LINDNER, H.R. (1976b) Refractoriness of ovarian adenylate cyclase following prolonged hormonal stimulation. Proc. 10th Int. Congr. Biochem., Hamburg, Abstr. 08-3-259, p. 450.

LAMPrecht, S.A., ZOR, U., KOCH, Y., SAlomon, Y. \& LINDNER, H.R. (1977) Mechanism of desensitization of ovarian adenylate cyclase to continued hormonal stimulation: dependence on de novo protein synthesis. In Ovarian Follicular Development and Function. Eds R. E. Midgley, Jr \& W. A. Sadler. Raven Press, New York.

LEE, C.Y. \& RYAN, R.J. (1972) Luteinizing hormone receptors: specific binding of human luteinizing hormone to homogenates of luteinized rat ovaries. Proc, natn. Acad. Sci. U.S.A. 69, 3520-3523.

LiEberman, M.E., BARNeA, A., BAuMINGER, S., TSAFriri, A., Collins, W.P. \& Lindner, H.R. (1975) LHeffect on pattern of steroidogenesis in cultured Graafian follicles of the rat: dependence on macro- 
molecular synthesis. Endocrinology 96, 1533-1542. Lindner, H.R., Tsafriri, A., LIEberman, M.E., Zor, U., Koch, Y., BAUminger, S. \& BARNeA, A. (1974a) Gonadotropin action on cultured Graafian follicles: induction of maturation division of the mammalian oocyte and differentiation of the luteal cell. Recent. Prog. Horm. Res. 30, 79-127.

LINDNER, H.R., ZOR, U., BAUMINGER, S., TSAFRIRI, A., LAMPrecht, S.A., KoCH, Y., ANTEBY, S. \& Schwartz, A. (1974b) Use of prostaglandin synthesis inhibitors in analyzing the role of prostaglandins in reproductive physiology. In Prostaglandin Synthesis Inhibitors, pp. 271-287. Eds J. R. Vane \& H. J. Robinson. Raven Press, New York.

Louvet, J.P., Harman, S.M. \& Ross, G.T. (1975) Effect of human chorionic gonadotropin, human interstitial cell stimulating hormone and human follicle stimulating hormone on ovarian weights in estrogen-primed hypophysectomized immature rats. Endocrinology 97, 1179-1186.

Louvet, J.P., HARman, S.M., Schreiber, J.R. \& Ross, G.T. (1975) Evidence for a role of androgens in follicular maturation. Endocrinology 97, 366-372.

LUNENFELD, B. \& ESHKoL, A. (1967) Immunology of human chorionic gonadotropin (hCG). Vitams Horm. 25, 137-190.

MabUCHI, I. (1976) Myosin from starfish eggs: properties and interaction with actin. Molec. Biol. 100, 569-582.

Makris, A. \& RyAN, K.J. (1975) Progesterone, androstenedione, testosterone, estrone and estradiol synthesis in hamster ovarian follicle cells. Endocrinology 96, 694-701.

Marsh, J.M., Butcher, R.W., Savard, K. \& SutherLAND, E.W. (1966) The stimulatory effect of luteinizing hormone on adenosine $3^{\prime} 5^{\prime}$-monophosphate accumulation in corpus luteum slices. J. biol. Chem. 241, 5436-5440.

Marsh, J.M., Mills, T.M. \& LeMaire, W.J. (1973) Preovulatory changes in the synthesis of cyclic AMP by rabbit Graafian follicles. Biochim. biophys. Acta 304, 197-202.

MeIJS-Roelofs, H.M.A., UILENBroeK, J.Th.J., DE JoNG, F.H. \& WelsChen, R. (1973) Plasma oestradiol-17 $\beta$ and its relationship to serum folliclestimulating hormone in immature female rats. $J$. Endocr. 59, 295-304.

MIDGLEY, A.R., JR (1973) Autoradiographic analysis of gonadotropin binding to rat ovarian tissue sections. Adv. exp. Med. Biol. 36, 365-378.

Mills, T.M., Telegdy, G. \& Savard, K. (1972) The synthesis and secretion of progesterone and $20 \alpha-$ hydroxy-4-pregnen-3-one by the rat ovary at various intervals after a single injection of hCG. Steroids 19, 621-637.

MuKherJeE, A.B. (1972) Normal progeny from fertilization in vitro of mouse oocytes matured in culture and spermatozoa capacitated in vitro. Nature, New Biol. 237, 397-398.

Neal, P. \& BaKer, T.G. (1973) Response of mouse ovaries in vivo and in organ culture to pregnant mare serum gonadotrophin and human chorionic gonadotrophin: examination of critical time intervals. $J$. Reprod. Fert. 33, 399-410.
Nilsson, L., Hillensjö, T. \& Ekholm, C. (1977) Periovulatory changes in LH-sensitivity of the rat follicular cyclic AMP system. Proc. 5th Int. Congr. Endocr., Hamburg, Abstr. 172, p. 69.

NimRod, A. \& LINDNER, H.R. (1976) A synergistic effect of androgen on the stimulation of progesterone secretion by FSH in cultured rat granulosa cells. Molec. Cell Endocr. 5, 315-320.

Nimrod, A., Erickson, G.F. \& Ryan, K.J. (1976) A specific FSH receptor in rat granulosa cells: properties of binding in vitro. Endocrinology 98, 5664.

NimRod, A., TSAFRIRI, A. \& LINDNER, H.R. (1977) Invitro induction of binding sites for human chorionic gonadotrophin in rat granulosa cells by follicle stimulating hormone. Nature, New Biol. (in press).

Nir, I., Ayalon, D., Tsafriri, A., Cordova, T. \& LINDNER, H.R. (1973) Suppression of the cyclic surge of luteinizing hormone secretion and of ovulation in the rat by $\Delta^{1}$-tetrahydrocannabinol. Nature, Lond. 243, 470-471.

Odeblad, E. \& Boström, H. (1953) A time-picture relation study with autoradiography on the uptake of labelled sulfate in the Graafian follicle of the rabbit. Acta radiol. 39, 137-140.

PAYNe, R.W. \& Runsen, R.H. (1958) The influence of estrogen and androgen on the ovarian response of hypophysectomized immature rats to gonadotropins. Endocrinology 62, 313-321.

Pedersen, T. (1970) Follicle kinetics in the ovary of the cycling mouse. Acta endocr., Copenh. 64, 304-323.

PegG, A.E., Lockwood, D.H. \& Williams-Ashman, H.G. (1970) Concentrations of putrescine and polyamines and their enzymatic synthesis during androgen-induced prostatic growth. Biochem. J. 117, 17-31.

PerRy, M.M., John, H.A. \& Thomas, N.S.T. (1971) Actin-like filaments in the cleavage furrow of newt eggs. Expl Cell Res. 65, 249-253.

Pincus, G. \& ENZManN, E.V. (1935) The comparative behaviour of mammalian eggs in vivo and in vitro. I. The activation of ovarian eggs. J. exp. Med.62, 665 675.

Prives, J., Silman, I. \& Amsterdam, A. (1976) Appearance and disappearance of acetylcholine receptor during differentiation of chick skeletal muscle in vitro. Cell 7, 543-550.

RAO, M.C. (1977) Hormone receptor regulation by LH: an active inducible process. In Ovarian Follicular Development and Function. Eds R. A. Midgley, Jr \& W. A. Sadler, Raven Press, New York.

Richards, J.S. \& Midgley, A.R., JR (1976) Protein hormone action: a key to understanding ovarian follicular and luteal cell development. Biol. Reprod. 14, 82-94.

Rodbell, M., LiN, M.C. \& Salomon, Y. (1974) Evidence for the interdependent action of glucagon and nucleotides on the hepatic adenylate cyclase system. J. biol. Chem. 249, 59-65.

Rondell, P. (1970) Follicular processes in ovulation. Fedn. Proc. Fedn. Am. Socs exp. Biol. 29, 18751879.

SAlomon, Y. \& Rodbell, M. (1975) Evidence for specific binding sites for guanine nucleotides in 
adipocyte and hepatocyte plasma membranes. $J$. biol. Chem. 250, 7245-7250.

Salomon, Y., Londos, C. \& Rodbell, M. (1974) A highly sensitive adenylate cyclase assay. Analyt. Biochem. 58, 541-548.

SALOMON, Y., YANOWSKy, A. \& LindNER, H.R. (1976) Modulation of LH-sensitive ovarian adenylate cyclase by guanosine nucleotides. Proc. 10th Int. Congr. Biochem., Hamburg, Abstr. 08-2-314, p. 444.

SAMmer, J.H., Rozek, L.F. \& Cammarata, P.S. (1968) Comparative smooth muscle and cardiovascular actions of prostaglandins $\mathrm{E}_{2}, \mathrm{~F}_{2 \alpha}$ and $\mathrm{F}_{2 \beta}$. In Prostaglandin Symposium of the Worcester Foundation for Experimental Biology, pp. 215-224. Eds P. W. Ramwell \& J. W. Shaw. Interscience Publishers, New York.

SchreIber, J.R., ReID, R. \& Ross, G.T. (1976) A receptor-like testosterone-binding protein in ovaries from estrogen-stimulated hypophysectomized immature female rats. Endocrinology 98, 1206-1213.

SHERIDAN, L.A. (1971) Dye movement and low resistance junctions between reaggregated embryonic cells. Devl Biol. 26, 627-636.

THORsøe, H. (1962) Development of polycystic ovaries following thyroidectomy. Acta endocr., Copenh. 40, 161-174.

TSAFRIRI, A., LINDNER, H.R. \& ZoR, U. (1971) In vitro induction of meiotic division in follicleenclosed ova by $L H$ and prostaglandin $E_{2}$. In Fertility and Sterility, pp. 404-411. Eds T. Hasegawa et al. Int. Congr. Ser. No. 278, Excerpta Med. Found., Amsterdam.

TSAFRIRI, A., LiNDNER, H.R., ZoR, U. \& LAMPRECHT, S.A. (1972) In vitro induction of meiotic division in follicle-enclosed rat oocytes by LH, cyclic AMP and prostaglandin $\mathrm{E}_{2}$. J. Reprod. Fert. 31, 39-50.

Tsafriri, A. \& Channing, C.P. (1975a) Influence of follicular maturation and culture conditions on the meiosis of pig oocytes in vitro. J. Reprod. Fert. 43, 149-152.

TsafriRI, A. \& Channing, C.P. (1975b) An inhibitor influence of granulosa cells and follicular fluid upon porcine oocyte meiosis. Endocrinology 96, 922-927.

TSAFriRi, A., LIEBerman, M.E., Koch, Y., Bauminger, S., Chobsiena, P., Sor, U. \& LindneR, H.R. (1976a) Capacity of immunologically purified FSH to stimulate cyclic AMP accumulation and steroidogenesis in Graafian follicles and to induce ovum maturation and ovulation in the rat. Endocrinology 98, 655-661.
Tsafriri, A., Pomerantz, S.H. \& Channing, C.P. (1976b) Inhibition of oocyte maturation by porcine follicular fluid: partial characterization of the inhibitor. Biol. Reprod. 14, 511-516.

Tyler, A., Monroy, A., KaO, C. \& Grundfest, H. (1956) Membrane potential and resistance of the starfish egg before and after fertilization. Biol. Bull. mar. Biol. Lab., Woods Hole 111, 153-177.

Virtumasen, P., Wright, K.H. \& Wallach, E.E. (1972) Effects of catecholamines on ovarian contractility in the rabbit. Obstet. Gynec. 39, 225-236.

WaLdman, A.A. \& GoldsteIn, J. (1973) Inhibition by heparin of globin messenger ribonucleic acid translation in a mammalian cell-free system. Biochemistry, N.Y. 12, 2706-2711.

Walles, B., Edvinsson, L., Falck, B., Nybell, G., Owman, Ch., SJöberg, N.-O. \& Svensson, K.-G. (1974) Modification of ovarian and follicular contractility by amines-a mechanism involved in ovulation? Eur. J. Obstet. Gynec. Reprod. Biol. 4, (Suppl.) pp. 103-107.

Walles, B., Edvinsson, L., Falck, B., Owman, Ch., SJöberg, N.-O. \& Svensson, K.-G. (1975) Evidence for a neuromuscular mechanism involved in the contractility of the ovarian follicular wall: fluorescence and electron microscopy and effects of tyramine on follicle strips. Biol. Reprod. 12, 239248.

ZACHARIAE, F. (1959) Acid mucopolysaccharides in the ovary and their rôle in the mechanism of ovulation. Acta endocr., Copenh., Suppl. 47, 33-38.

ZelezNIx, A.J., MidGLeY, A.R., JR \& ReicheRT, L.E., $J_{R}$ (1974) Granulosa cell maturation in the rat: increased binding of human chorionic gonadotropin following treatment with follicle-stimulating hormone in vivo. Endocrinology 95, 818-824.

ZoR, U. \& LAMPRECHT, S.A. (1977). Mechanism of prostaglandin action in endocrine glands. In Biochemical Actions of Hormones, Vol. 4. Ed. G. Litwack. Academic Press, New York.

ZOR, U., LAMPRECHT, S.A., KOCH, Y. \& LINDNER, H.R. (1975) Desensitization of Graafian follicles by gonadotropins or prostaglandin $\mathrm{E}_{2}$ to stimulation of adenylate cyclase by the homologous hormone. (Proc. 57th A. Meeting, Endocr. Soc.) Endocrinology 96A, Abstr. 628, p. 365.

ZoR, U., LAMPRECHT, S.A., Misulovin, Z., КоCH, Y. \& LINDNER, H.R. (1976) Refractoriness of ovarian adenylate cyclase to continued hormonal stimulation. Biochim. biophys. Acta 428, 761-765. 